\title{
Towards a Sustainable Agriculture: Strategies Involving Phytoprotectants against Salt Stress
}

\author{
José Ramón Acosta-Motos ${ }^{1,2}$, Consuelo Penella ${ }^{1,3}{ }^{\mathbb{C}}$, José A. Hernández $1, * \mathbb{C}$, \\ Pedro Díaz-Vivancos ${ }^{4}{ }^{\mathbb{D}}$, María Jesús Sánchez-Blanco ${ }^{5}$, Josefa María Navarro ${ }^{6}{ }^{\circ}$, \\ María José Gómez-Bellot ${ }^{5}$ and Gregorio Barba-Espín ${ }^{1}$ (I) \\ 1 Group of Fruit Tree Biotechnology, Department of Plant Breeding, CEBAS-CSIC, 30100 Murcia, Spain; \\ jacosta@cebas.csic.es (J.R.A.-M.); cpenella@valgenetics.com (C.P.); gbespin@cebas.csic.es (G.B.-E.) \\ 2 Universidad Católica San Antonio de Murcia (UCAM), Cátedra de Emprendimiento en el Ámbito \\ Agroalimentario UCAM-Santander, Campus de los Jerónimos, 30107 Murcia, Spain \\ 3 Valgenetics, Parc Cientific Univertisat de Valencia, 46980 Paterna, Valencia, Spain \\ 4 Department of Plant Biology, Faculty of Biology, University of Murcia, Campus de Espinardo, \\ 30100 Murcia, Spain; pdv1@um.es \\ 5 Irrigation Department, CEBAS-CSIC, 30100 Murcia, Spain; quechu@cebas.csic.es (M.J.S.-B.); \\ mjgb@cebas.csic.es (M.J.G.-B.) \\ 6 Equipo de Riego y Fisiología del Estrés, Departamento de Recursos Naturales, Instituto Murciano de \\ Investigación y Desarrollo Agrario y Alimentario (IMIDA), 30150 La Alberca, Murcia, Spain; \\ josefam.navarro2@carm.es \\ * Correspondence: jahernan@cebas.csic.es; Tel.: +34-968-396-200
}

Received: 19 December 2019; Accepted: 29 January 2020; Published: 1 February 2020

\begin{abstract}
Salinity is one of the main constraints for agriculture productivity worldwide. This important abiotic stress has worsened in the last 20 years due to the increase in water demands in arid and semi-arid areas. In this context, increasing tolerance of crop plants to salt stress is needed to guarantee future food supply to a growing population. This review compiles knowledge on the use of phytoprotectants of microbial origin (arbuscular mycorrhizal fungi and plant growth-promoting rhizobacteria), osmoprotectants, melatonin, phytohormones and antioxidant metabolism-related compounds as alleviators of salt stress in numerous plant species. Phytoprotectants are discussed in detail, including their nature, applicability, and role in the plant in terms of physiological and phenotype effects. As a result, increased crop yield and crop quality can be achieved, which in turn positively impact food security. Herein, efforts from academic and industrial sectors should focus on defining the treatment conditions and plant-phytoprotectant associations providing higher benefits.
\end{abstract}

Keywords: antioxidative metabolism; arbuscular mychorrhizal fungi (AMF); melatonin; osmoprotectans; phytohormomes; plant growth-promoting rhizobacteria (PGPR); salinity

\section{Introduction}

Plants are increasingly subjected to a variety of environmental stresses that adversely impacts plant growth and productivity [1]. In a recent report, the food and agricultural organization (FAO) highlighted the necessity of devising strategies to face the impacts of climate change on agriculture and food security worldwide [2]. Among environmental factors, salinity has a major impact, as most crop plants are salt stress-sensitive [3,4].

Soil salinity includes saline, sodic and alkaline soils, characterized by high salt content, high sodium cation $\left(\mathrm{Na}^{+}\right)$content, and high $\mathrm{pH}$, respectively [5]. Soil salinity affects approximately 800 million hectares of farmlands on a world scale [5]. Saline soil is characterized by an electrical conductivity of $4 \mathrm{dS} \mathrm{m}^{-1}$ generating an osmotic pressure of about $0.2 \mathrm{MPa}$ and decreasing the yields 
of most crops significantly [4]. Increased water scarcity in semi-arid areas, as a consequence of both climate change (low rainfall and high temperatures) and population growth, will increase secondary salinization, i.e., salinization, due to human activity. In this sense, the use of unconventional water resources, such as municipal wastewater from wastewater treatment plants (WWTP) is one of the most important and current practices for sustainable agriculture. WWTP supplies an important amount of beneficial nutrients, which can improve soil fertility. However, its use may also result in serious problems associated with salinity and high boron concentrations [6-13].

Halophytes (1\% of the world's flora) are plants able to survive and reproduce in saline environments of $200 \mathrm{mM} \mathrm{NaCl}$ or more. Relevant examples include Salicornia sp, Spartina alterniflora Loisel, Anemopsis californica Nutt. and Atriplex sp., among others. Facultative halophytes occur on slightly saline soils, and include many species of Poaceae, Cyperaceae and Juncaceae families such as Glaux maritima L., Plantago maritima L., Aster tripolium L. and Chenopodium quinoa Kuntze. The major group of plants are glycophytes or halophobic, which represent $98-99 \%$ of the world's flora. Within them, the vast majority are non-resistance to salt, and therefore, unable to successfully grow in saline soils. However, a small number of glycophytes (facultative glycophytes or indifferent to salt) may develop some resistance to salt and show higher levels of sodium in their tissues. As representative examples of this latter group, there are ecotypes of Festuca rubra L., Agrostis stolonifera L, Phragmites communis Cav., species or subspecies of Puccinellia, Lotus, Atriplex hastata L., Vigna unguiculata L. Walp. and sugar beet [14,15].

In the plant, salt stress first causes an ion-independent growth reduction driven by stomatal closure and inhibition of cell expansion, and in the long term, by ion toxicity, due to a cytosol over-accumulation of $\mathrm{Na}^{+}$and $\mathrm{Cl}^{-}$. This leads to a nutrient imbalance and the interference with many physiological processes as a lower energy production through photophosphorilization and phosphorylation in the respiratory chain, and an affected assimilation of nitrogen and protein synthesis, which in turn cause premature senescence and ultimately cell death [16]. In addition, salt stress is coupled with an oxidative stress, due to an over-accumulation of reactive oxygen species (ROS) at subcellular level [17-20]. As a consequence, under saline conditions, plants activate a variety of physiological and biochemical mechanisms to acquire resistance against saline stress, which include morphological changes, ion distribution, photosynthesis, and antioxidative metabolism activation [increased activity of reactive oxygen species (ROS)-scavenging enzymes and non-enzymatic antioxidant contents] [21-24].

To fulfill increasing food demands of the population, strategies towards enhanced crop resilience to environmental challenges are desirable. Over the past few decades, the use of phytoprotectants has become a hotspot in the amelioration of salt stress in crop plants. The present review compiles knowledge on the use of arbuscular mycorrhizal fungi (AMF), plant growth-promoting rhizobacteria (PGPR), osmoprotectants, melatonin, phytohormones, ROS and reactive nitrogen species (RNS) as natural phytoprotectants under salt stress.

\section{Phytoprotectants of Microbial Origin}

\subsection{Arbuscular Mycorrhizal Fungi (AMF)}

Arbuscular mycorrhizal fungi (AMF) are beneficial microorganisms which increase soil fertility of agricultural and natural ecosystems [25]. The term mycorrhiza applies to about 6000 different fungi, which develop symbiotic interactions with a huge range of plants. They build a direct physical interaction between plant roots and soil and represent an essential part of natural habitats [26]. Formation of AMF symbiosis brings numerous advantages to both symbionts, since the plant improves its uptake of water and mineral nutrients, while the fungus uses up to $20 \%$ of net photosynthate to support its growth and respiration processes [25]. Moreover, AMF may enhance plant resistance to biotic and abiotic stresses, among other functions [25,27].

AMF are able to live in saline ecosystems, since some of them have been isolated in these conditions [28], even though their growth and colonization of plants is usually reduced, due to specific ion toxicity and osmotic effects of salts [29-31]. AMF symbiosis has been found to enhance 
salinity tolerance in different host plants, such as cucumber, lettuce, tomato, maize, acacia and citrus [32-37]. AMF increase absorption of soil water through the mycelium and mobilization in the plant, enhance soil-root contact, reduce the deleterious effects of phytotoxic ions on the integrity of the plasmatic membrane and cell organelles, change phytohormone balance, increase antioxidant defenses (both enzymatic and non-enzymatic) and promote the expression of salt stress-related genes [37-41]. In addition, AMF may increase root hydraulic conductivity at low water potential [42], promote and change root system architecture, and enhance stomatal conductance by improving the gas exchange capacity $[31,37,39,43]$. Moreover, it has been found that in salt-stressed plants, chlorophyll synthesis is less interfered when plants are inoculated with AMF [31]. Thus, AMF can be implemented as phytoprotectants increasing growth potential and reducing fertilizer and water use. Herein, it is essential to make an accurate selection of AMF to ensure the effectiveness of the fungi species under salinity.

The mechanisms by which AMF are able to enhance salinity tolerance in plants are similar to those implied in drought conditions, since the first plant symptom under saline conditions is a water deficit in the plant, due to decreased water uptake. Inoculation with AMF results in a better soil structure under salt stress, due to intertwining of extraradical mycorrhizal hyphae and gluing of glomalin produced by AMF and roots [44], thereby providing relatively higher available water content [45]. Moreover, it improves nutritional status by the transportation of mineral nutrients across the root-soil interface, generating resistance in plants under osmotic stress conditions. Several studies show the enhanced nutritional status of AMF treated plants under osmotic stress [29,37,46]. AMF act as an initial defensive barrier, discriminating phytotoxic ions, and thus, favoring the absorption and selective transport of beneficial mineral nutrients. AMF reduces the mobilization of $\mathrm{Na}^{+}$to plant tissues avoiding its concentration to reach harmful levels, because of their capacity to maintain this ion in structures, such as root cell vacuoles, vesicles and intraradical mycelium [27]. These fungal mechanisms help in the compartmentalization of toxic ions and preventing their accumulation from reaching plant tissues [47]. In this regard, lower concentrations of leaf $\mathrm{Na}^{+}$were observed in mycorrhizal than in non-colonized plants subjected to saline stress [30,37,48]. Some authors claim that the decrease in leaf $\mathrm{Na}^{+}$content could be partially due to a dilution effect, through an increase in dry matter accumulation [49]. AMF can reduce $\mathrm{Cl}^{-}$and $\mathrm{Na}^{+}$content and enhance beneficial nutrients, such as $\mathrm{P}, \mathrm{N}$, $\mathrm{K}^{+}, \mathrm{Ca}^{2+}$ and $\mathrm{Mg}^{2+}$ in different plants, such as citrus, wheat and ornamental plants $[37,48,50]$, which consequently increase the $\mathrm{K}^{+} / \mathrm{Na}^{+}, \mathrm{Mg}^{2+} / \mathrm{Na}^{+}, \mathrm{Ca}^{2+} / \mathrm{Na}^{+}$and $\mathrm{K}^{+} / \mathrm{N}$ ratios $[30,51]$. Improved plant nutrition by AMF symbiosis allows cells to regulate flowing ions more efficiently, enhancing nutrient uptake by transport or availability through mycorrhizal hyphae, conducive to improve salt resistance of mycorrhizal plants. Phosphorous $(\mathrm{P})$ levels in the plant display significant increases by AMF colonization [25]. The better P nutrition of mycorrhizal plants has been related to the higher salinity tolerance of AMF plants in citrus and Jatropha curcas L. plants. [37,52]. In general, a better P nutrition in AMF-inoculated plants could improve their antioxidant enzyme activities [53], although the response of the individual enzymes varies in function of the fungal species and the hostplant interactions [54]. In this context, AMF symbiosis has been observed to enhance the antioxidative system in order to cope with the ROS generated by salinity in Olea europaea L. [55], and tomato [53]. Moreover, in citrus plants, it has been suggested that AMF decrease the antagonistic effect of $\mathrm{Na}^{+}$on $\mathrm{Mg}^{2+}$ uptake, enhancing the chlorophyll content, and hence, improving photosynthetic efficiency and plant growth [37]. As a result of the mechanisms described above, AMF enhance plant nutrient absorption, which helps to withstand saline stress conditions [31,51]. In this sense, the higher water uptake is facilitated, since the external hyphae network allows host plants to uptake more water from soils, elevating leaf water potential $[39,43,45]$.

On the other hand, some authors reported adverse effects of AMF when plants are fertilized [56,57]. Some recent studies have been focused on the feasibility of using reclaimed municipal wastewater from WWTP (as an alternative water resources) together with AMF inoculation [50,58,59]. In addition to high levels of $\mathrm{Na}^{+}$and $\mathrm{Cl}^{-}$, and depending on its source and treatment, reclaimed wastewater 
may contain high levels of beneficial elements, such as $\mathrm{P}, \mathrm{K}^{+}, \mathrm{Ca}^{2+}$ and $\mathrm{Mg}^{2+}$, which can alter AMF function [58]. Gómez-Bellot et al. [59] found that the nutrient content of saline reclaimed water improved the nutritional status of euonymus plants, but no additive effect was observed when AMF was added to the same plants. In fact, the beneficial mycorrhizal effect was clearer in mycorrhizal plants irrigated with conventional water. These results are not in accordance with those found in lettuce [58], where irrigation with similar reclaimed wastewater $\left(4 \mathrm{dS} \mathrm{m}^{-1}\right)$ and applying the same AMF colonization had a synergetic effect on promoting plant growth. Nevertheless, the inoculation of the same AMF using reclaimed wastewater with higher salinity $\left(6 \mathrm{dS} \mathrm{m}^{-1}\right)$, improved the physiological behavior of laurustinus plants growing in soil, by ameliorating the negative effects of toxic ions [50]. Moreover, results suggested that plant mycorrhizal inoculation was more effective when the saline water for irrigation displayed a higher concentration of toxic ions, but lower content of beneficial nutrients [58,59].

At the molecular level, the elucidation of the mechanisms implicated in AMF symbiosis under salt stress has advanced over the past decade [60-64]. The stress perception is channelized inside the nucleus, resulting in the expression of multiple stress-responsive genes, related to cellular protection against the stress (e.g., antioxidants, late embryogenesis abundant proteins and chaperons) or implicated on the perception, transmission and transcription of the signal $[38,60,61]$. Recent studies revealed the molecular mechanisms of high $\mathrm{K}^{+} / \mathrm{Na}^{+}$ratio in mycorrhizal plants, which are based on the induced expression of genes involved in $\mathrm{K}^{+}$acquisition and $\mathrm{Na}^{+}$extrusion to the soil [61-64]. For example, in Oryza sativa L., up-regulation of OsNHX3 (sodium/hydrogen exchanger) by AMF allows the compartmentalization of $\mathrm{Na}^{+}$into the vacuole [63]. In black locust, AMF induced the expression of genes encoding for membrane transport proteins and aquaporins (SOS1, HKT1, NHX1, and SKOR), which contributes to maintaining ion homeostasis [64]

The current trend towards the use of biological products, such as mycorrhizal inoculation is helping to increase the efficiency of intensive agriculture $[65,66]$. Nowadays, the combination of AMF inoculation and controlled deficit irrigation in drought or salinity conditions are increasingly applied in arid and semi-arid areas [67-71] However, in order to be an effective and sustainable tool for agriculture, numerous factors have to be taken into consideration. Thereby, the fungal colonization in open-field experiments is more productive in terms of root biomass experiments, which is associated with the growth constrains of containerized roots in a greenhouse. Contrarily, shoot biomass, plant nutrition and yield seem to be independent on the location factor [72]. Another relevant factor determining the applicability of the AMF-plant association is the source of inoculant. In this sense, native AMF obtained from saline soils may cope with salt stress more efficiently compared to other AMF [73,74]. Therefore, the type of stress may determine the type AMF. Moreover, aspects, such as AMF evaluation under multiple environmental stressors, and the identification of specific AMF strain/plant species combinations, should be taken into account to obtain the most effective responses. Herein, it was observed that single species inoculation experiments use to confer higher benefits to plants in greenhouse trials, whereas, in open-field experiments where multiple stresses are acting, a more complex fungal community may provide a better output [75].

\subsection{Plant Growth-Promoting Rhizobacteria (PGPR)}

Plant growth-promoting rhizobacteria (PGPR) [76] referred to free-living soil bacteria that establish beneficial associations with plants. Around 1 to $2 \%$ of bacteria are classified as PGPR [77]. Among the diverse genera that compose the group, Pseudomonas and Bacillus spp are prevalent [78]. Independently on the strategy to promote plant growth, PGPR colonize either the root surface, the radicular tissues, or the rhizosphere [79]. Their beneficial action relies on indirect and direct mechanisms. The indirect stimulation of plant growth occurs by competing against plant pathogen, by means of antagonistic compounds produced by the PGPR or by induced resistance to pathogens in the plants [80-85]. This may include the production of antibiotics [86,87], lysing enzymes as proteases, cellulases, glucanases, chitinases, lactonases [88-90], siderophores to chelate iron [91,92] or other 
toxic compounds as cyanide $[93,94]$, as well as volatiles compounds, such as dimethyl disulfide and 2-methylpentanoate $[95,96]$. On the other hand, the direct growth promotion occurs by increased nutrient availability (by nitrogen-fixing or solubilization of $\mathrm{P}$ and $\mathrm{K}^{+}$, among other nutrients), altered phytohormone and enzymatic production [97-99], and modulated osmotic balance [100,101]. PGPR has also been associated with modulation of ethylene level, increased nutrient solubilization and root absorption and production of phytohormones [102]. In addition, Mohamed and Gomaa [103] found that PGPR enhanced total chlorophyll pigments in radish plants grown under salinity, due to enhanced levels of proline and free total amino acids, which slowed down the chlorophyll degradation.

In agreement with the mechanisms described above, numerous studies have reported improved vegetative development and increased yield of different plant species by the utilization of PGPR [104-107]. Likewise, PGPR have also been applied to reduce the use of chemical fertilizers and pesticides, as a consequence of the more efficient nutrient uptake and the plant protection conferred by PGPR $[108,109]$. This results in improved economic viability, soil fertility, and environmental sustainability [110-112]. In this sense, several PGPR formulations are currently available as commercial products for agricultural production $[113,114]$. The ability to develop plant responses to certain PGPR may rely on the specificity of the interaction between the bacteria and the plant, and on the soil conditions $[115,116]$. Hence, efforts are focused worldwide on evaluating a wide range of rhizobacteria conferring resilience against environmental stressors, such as salt stress [117-120]. Overall, physiological and chemical responses in the modulation of abiotic stress in PGPR-inoculated plants have been termed as "induced systemic tolerance" (IST) [121]. Recently, a meta-analysis study has reported that PGPR inoculation induces more ostensible plant responses in non-optimal conditions [106]. In addition, PGPR effects mitigating salt stress have also been noticed in early plant stages of canola, lettuce, rice, chickpea and mung bean [122-124], wheat seedlings [125], and potato [126].

PGPR-inoculated plants grown under salinity conditions generally display an improved nutrient and water balance and enhanced rooting and plant growth [127]. $\mathrm{Na}^{+}$reduction in leaves has been observed by PGPR inoculation of wheat [128]. Likewise, an altered selectivity of $\mathrm{Na}^{+}, \mathrm{K}^{+}$and $\mathrm{Ca}^{2+}$ have been reported, resulting in an increased $\mathrm{K}^{+} / \mathrm{Na}^{+}$ratio, and $\mathrm{N}, \mathrm{P}$, and $\mathrm{K}^{+}$uptake in several crops, such wheat and maize [128,129]. In other cases, inoculated plants (soybean, lettuce and pepper) maintained their osmotic homeostasis by higher proline levels [130-132]. Moreover, an overall increase in the water use efficiency was observed in PGRP-inoculated plants under salt stress [117]. Furthermore, enhancement in the activities of antioxidant enzymes to cope with salinity-induced oxidative stress has been reported in lettuce [131], wheat plants [133], and Phaseolus vulgaris L. [134]. In addition, several studies showed that certain PGPR diminish the biosynthesis of salt-induced ethylene in several crops, such as tomato, canola and maize treated plants $[117,135,136]$.

To date, our knowledge on beneficial microbes diversity, mechanism of action, application, and also physiological and biochemical inoculated plant responses, has facilitated the emergence of numerous PGPR commercial products. In the last decades, a large number of studies have demonstrated beneficial PGPR effects in both laboratory and greenhouse studies. However, fewer studies conducted field trials, and more comprehensive knowledge related to PGPR and plant interaction in different agro-ecosystems is required. The beneficial effects of PGPR are modulated by diverse growth habitats, native microbial communities and environmental conditions. For example, weather fluctuations influence the effectiveness of PGPR [137], which has to be considered in field experiments and in PGPR applications in agriculture. Regarding the molecular aspects of PGPR action, the expression of novel plant genes, such as SOS1, which codifies for a plasma membrane $\mathrm{Na}+\mathrm{H}+$ antiporter [138], was found to be promoted in PGPR-applied wheat shoots and roots, resulting in improved salt stress resistance [139]. Moreover, the use of genes from halo-tolerant PGPR may confer salt tolerance to transgenic plants; for example, expression of Bacillus subtilis proline biosynthesis (ProBA) gene conferred salt tolerance in transgenic Arabidopsis through increased proline production [140]. Likewise, halotolerant properties of PGPR, such as Enterobacter ludwigii and other enterobacters rely on the role of $\mathrm{Na}+\mathrm{H}+$ antiporters, such as NhaA. In conclusion, it is notable that PGPRs are postulated as an eco-friendly and versatile 
tool to stimulate crops to mitigate adverse conditions [89,127,141,142]. As our knowledge expands, more commercial formulations may be designed, accomplishing more sustainable agrarian systems.

\section{Nitrogen-containing Phytoprotectants}

\subsection{Osmoprotectants: Proline, Glycine Betaine and Polyamines}

The accumulation of osmolytes, i.e., low molecular weight water-soluble compounds, is a common strategy of many plants to cope with water deficit and salt stress as they confer stress tolerance without affecting cellular machinery [143]. Among them, the most common osmolytes are glycine betaine (GB), proline (Pro) and polyamines (PA) [143-146]. The accumulation of these molecules in the cytosol and organelles decreases plant internal osmotic potential, in response to the decrease in external soil osmotic potential, due to excessive accumulation of phytotoxic ions in the substrate. Consequently, the cell membrane and macromolecules integrity are maintained.

Pro biosynthesis from glutamate involves $\Delta 1$-pyrroline-5-carboxylate synthetase and glutamate dehydrogenase enzyme reactions. Pro accumulation depends on the balance between their biosynthesis and degradation rates, the latter catalyzed by the mitochondrial enzyme proline dehydrogenase (PDH) [147]. Studies on Pro mode of action have focused on its capacity to mediate osmotic adjustment, stabilize subcellular structures and ROS scavenging during salt stress. Likewise, increased Pro in response to stress contributes to maintaining the $\mathrm{NAD}(\mathrm{P})^{+} / \mathrm{NAD}(\mathrm{P}) \mathrm{H}$ ratio [148]. Yang et al. [147] reported Pro accumulation as a result of increased biosynthesis and inhibition of its degradation by $\mathrm{H}_{2} \mathrm{O}_{2}$.

Pro supplements were proven to confer salt tolerance and enhance plant growth by improving the antioxidative enzyme system, photosynthetic activity, water status, and consequently, plant performance in olive tree [149]. Moreover, Pro treated plants displayed lower soluble sugars content, which shows the role of Pro as osmoprotectant [149]. The application of 50-100 mM Pro in the irrigation water improved germination, seedling growth and chlorophyll contents of sorghum and wheat $[150,151]$. In another study, the application of seaweed extracts ameliorated the negative impacts of salt stress by increasing aminoacids, such as serine, threonine and Pro in roots of chickpea plant [152]. In soybean, $25 \mathrm{mM}$ Pro applied as foliar spray increased nitrogen fixation and specific nodule activity [130]. Moreover, seed spraying of P. vulgaris at low Pro concentration (5 mM) alleviated oxidative stress and enhanced plant growth, increased carotenoids and ascorbate contents, and the endogenous levels of proline [153]. However, although the beneficial effects of Pro applied exogenously, toxic effects have also been reported. For example, Pro applied at high concentration in tomato resulted in ion imbalance and poor plant growth [154]. In rice, $30 \mathrm{mM}$ Pro in the irrigation water ameliorated the negative effects of salt stress, whereas, higher concentrations (40-50 mM Pro) resulted in deleterious for plant growth [155]. Such toxic effect of exogenous Pro has been explained by the fact that high concentrations may mimic the effects of $C d$, as reported in rice seedlings [156]

GB is a quaternary ammonium compound that is a highly effective osmoprotectant in many plant species in response to salt stress [143-146]. The metabolic pathway for GB biosynthesis in plants involves two enzymes, i.e., betaine aldehyde dehydrogenase (BADH) and choline monooxygenase (CMO), which are located in the chloroplasts [157]. This pathway takes place in some crops, like cotton and sugar beet, as well as in many drought-tolerant and highly salt-tolerant wild plants, including halophytes [158]. Evidence indicates that plants are able to translocate foliar-applied GB from their leaves to other organs mainly via phloem, where it may ameliorate stress tolerance by maintaining membrane integrity, adjusting cell osmolarity, and protecting the photosynthetic complex, especially photosystem II, among other mechanisms [159]. Furthermore, GB also acts in maintaining Rubisco activity and enhancing stomatal conductance [159]. GB accumulation has long been a target for engineering stress resistance. Remarkably, it has been found that transgenic carrot overexpressing $B A D H$ gene accumulated high amounts of GB, which in turn resulted in high salt tolerance at high salt concentrations (up to $400 \mathrm{mM}$ ) [160]. Likewise, the transgenic rice plants converted high levels 
of exogenously applied betaine aldehyde (up to $10 \mathrm{~mol} \mathrm{~m}^{-3}$ ) to glycinebetaine more efficiently than did wild-type plants acquiring greater resistance to salinity [161]. Conversely, transgenic rice plants overexpressing $C M O$ gene were not effective for accumulation of GB and improvement of productivity, although displayed enhanced tolerance to salt stress in the seedling stage [162].

The use of GB applied exogenously to plants that accumulate little or none of this compound may alleviate the harmful effects of environmental stress [157]. There are several reports displaying the beneficial effects of exogenous application of GB on plant growth and final crop yield under salt stress or drought. Examples include those in rice, sunflower, maize, canola, eggplant, pepper, ryegrass, lettuce, safflower, pigeon pea, soybean, wheat and tomato [163-175]. Some reports have also shown that application of GB facilitated the accumulation of other osmotic substances, such as free Pro and soluble sugars in plant organs under salt stress conditions $[168,176]$. This has been attributed to a protective role of GB on key enzymes that catalyze the biosynthesis of soluble free proline [176].

PA are polybasic aliphatic amines extensively disseminated in plants and implicated in numerous cellular functions [177-179]. The most common PA present in halophytes are: cadaverine (Cad), putrescine (Put), spermidine (Spd) and spermine (Spm) $[180,181]$. These compounds can be located in all plant organs, being implicated in a plethora of metabolic processes, such as leaf senescence, morphogenesis, protection of photosynthetic tissues, growth and embryogenesis, serving as bioindicators of stress-tolerant genotypes [182-188]. Moreover, PA regulates the antioxidant machinery acting as free-radical scavengers [189], and contribute to abiotic stress signaling [190]. In these processes, PA have been proven to activate the expression of genes associated with stress response and establish the interaction with other metabolic pathways [190,191]. PA bind covalently to biomacromolecules to form bound PA, which usually exerts stronger physiological activity than free PA [192].

The use of exogenous PA and transgenic plants have demonstrated an important role of these compounds in a variety of adaptive responses to salt stress $[185,193,194]$. Exogenous application of Spm, Spd, Put and Cad resulted in improved plant growth by means of improved photosynthesis and activation of antioxidative metabolism, which ameliorate the negative effects of salt stress [195-197]. Ikbal et al. [184] reported that enhanced S-adenosylmethionine decarboxylase (SAMDC) activity would maintain high PA levels in salt-stressed micropropagated grapevine (Vitis vinifera L.) plants. The application of exogenous Spd $(0.1$ and $1 \mathrm{mM})$ enhanced salt tolerance $(150 \mathrm{mM} \mathrm{NaCl})$ of Panax ginseng C.A. Mey. plants by enhancing the antioxidant defenses and thus, alleviating salt-induced oxidative stress. As a result, Spd application increased plant growth, shoots and roots relative water content, and prevented chlorophyll degradation under salinity conditions [185]. More recently, Nahar et al. [187] observed that the pre-treatment of mung bean seedlings with PA- $-2.2 \mathrm{mM}$ of either Put, Spd or Spm-improved the response to salt stress $(200 \mathrm{mM} \mathrm{NaCl})$ by reducing cellular $\mathrm{Na}^{+}$ accumulation, maintaining ion homeostasis, and by increasing the levels of antioxidant defenses, including ascorbic acid (AsA) and glutathione (GSH), as well as catalase (CAT), dehydroascorbate reductase (DHAR), glutathione peroxidase (GPX), and glutathione reductase (GR) activities [187]. Similarly, the up-regulation of SAMDC expression induced accumulation of Spd and Spm, resulting in an attenuation of salt stress in cucumber and grasses $[198,199]$. Under salt stress, the growth of transgenic rice seedlings overexpressing $S A M D C$ was improved, in comparison to non-transformed rice plants, which was correlated with a three to four-fold increase in Spd and Spm [200].

In summary, exogenous application of osmoprotectants can be a suitable means to increase salt tolerance in different crop species by regulating osmotic potential, reducing the accumulation of phytotoxic ions and protecting essential macromolecules, such as proteins from the photosynthetic complex.

\subsection{Melatonin}

Melatonin (N-acetyl-5-methoxytryptamine) is a ubiquitous molecule derived from the aminoacid tryptophan which is present in almost all living organisms, including plants [201]. Melatonin was 
named because of its ability to pigment the skin of animals, such as fish, reptiles, and amphibians [202]. Numerous studies have demonstrated its role in seed germination, plant growth, organogenesis, and leaf and fruit senescence. All these functions might be mediated by the effect of melatonin up-regulated genes related to a multitude of cellular functions, including primary metabolism, redox processes, lipid and carbohydrate metabolism, cell cycle, DNA replication, photosynthesis, and senescence-associated genes, among others [203,204]. It also enhances the secondary metabolism and protecting the photosynthetic machinery. Moreover, it establishes crosstalk with plant hormones and polyamines, among other molecules, and regulates its own biosynthesis [205-210]. In addition, it is well established that melatonin helps to protect plants against different abiotic stresses, including salt stress [203,204,211,212].

Melatonin is synthesized by at least four different alternative biosynthetic routes, all implying serotonin as an intermediary, indicating that this molecule is a hub intermediate for this purpose in plants [213]. Each of the four known alternative routes for the biosynthesis of melatonin takes place in different organelles, where the production of the intermediates and melatonin occurred. Its chemical structure confers melatonin amphiphilic properties, which favors its movement through the plasma membranes and entry into different cellular compartments, especially chloroplasts, endoplasmic reticulum and cytoplasm [213].

In relation to salt stress, the functions of melatonin can be classified as follows: Activation of antioxidant defenses to protect plants against loss of water and physiological injuries associated with salinity, enhancement of photosynthesis, boost of ion homeostasis, regulation of plant hormone metabolism, and stimulation of polyamine metabolism pathway [212,214-218]. Under salt stress, the activities of ascorbate peroxidase (APX), peroxidase (POD), superoxide dismutase (SOD), CAT, GR, and GPX in maize seedlings treated with melatonin increased significantly compared to the levels on non-treated seedlings [215,219]. Similarly, the exogenous application of melatonin in Malus hupehensis Pamp. seedlings reduced hydrogen peroxide $\left(\mathrm{H}_{2} \mathrm{O}_{2}\right)$ and superoxide radicals $\left(\mathrm{O}_{2} \cdot{ }^{-}\right)$levels by activating the same antioxidant enzymes [220]. In addition, the contents of non-enzymatic antioxidants, such as GSH and AsA in cucumber subjected to salinity conditions were higher when ROS interacted with melatonin [216]. This evidence implies that exogenous application of melatonin could improve the antioxidant defenses (non-enzymatic and enzymatic) of plants mainly by removing the ROS generated by salt stress.

Globally, the application of exogenous melatonin helps plants to better perform photosynthesis by avoiding chlorophyll degradation and stomatal closure, due to salt stress [221-223]. The application of exogenous melatonin $(50-150 \mu \mathrm{M})$ in cucumber significantly improved plant responses to salt stress by increasing maximum quantum efficiency of PSII, chlorophyll levels and leaf net photosynthetic rate [216]. Similarly, in watermelon, pretreatment with melatonin (50-500 $\mu \mathrm{M})$ clearly favored salt tolerance by improving leaf net photosynthetic rate and stomata opening [224]. Melatonin significantly upregulated MdNHX1 and MdAKT1 transcript levels in M. hupehensis seedlings subjected to salt stress, providing a decrease in $\mathrm{Na}^{+}$concentrations ${ }^{+}$and an increase in $\mathrm{K}^{+}$that incremented $\mathrm{K}^{+} / \mathrm{Na}^{+}$ ratio [220]. In a similar way, melatonin provoked a remarkable increase in $\mathrm{K}^{+} / \mathrm{Na}^{+}$ratio in shoots of maize seedlings when grew under salt stress [215]. Other genes, such as $A K T, N H X$, and SOS seem to be correlated with better ion homeostasis coherent with high $\mathrm{K}^{+}$levels, and consequently, with a greater $\mathrm{K}^{+} / \mathrm{Na}^{+}$ratio [225]. Melatonin also up- or down-regulates the expression of genes related to hormonal homeostasis, which encode for enzymes of the biosynthesis or degradation of plant hormones, such as indole-3-acetic acid, gibberellins (GA), abscisic acid (ABA) cytokinins, ethylene, salycilic acid (SA) and jasmonic acid (JA) [226-229].

In conclusion, melatonin participates in a variety of molecular stress mechanisms in plants related to the response to biotic and abiotic stresses. In general, increased melatonin levels-as a consequence of either a stressful situation or exogenous application-results in an improved stress tolerance mediated by changes in the hormone profile, antioxidative metabolism and expression 
of specific stress-responsive genes [208,210,227,230-234]. Recently, the novel characterization of a melatonin receptor in Arabidopsis opens up melatonin as a new phytohormone [235].

\section{Phytoprotectants Related to Antioxidative Metabolism and Plant Hormones}

\subsection{Antioxidative Metabolism}

Many studies have associated pre-treatments with different ROS, especially $\mathrm{H}_{2} \mathrm{O}_{2}$, reactive nitrogen species (RNS, especially nitric oxide (NO)), ascorbic acid (AsA), and plant hormones, such as gibberellins (GA) and salicylic acid (SA), with an improved resilience of plants against different abiotic stresses, such as salinity. Despite their harmful nature, $\mathrm{H}_{2} \mathrm{O}_{2}$ has a dual role in plant stress response; at high concentration, $\mathrm{H}_{2} \mathrm{O}_{2}$ is deleterious for the cell function, whereas, at low concentration it may act as a signal molecule in a variety of biotic and abiotic stresses [236,237]. Consequently, ROS production is tightly controlled in plant cells by enzymatic and non-enzymatic antioxidants. It has been reported that $\mathrm{H}_{2} \mathrm{O}_{2}$-priming seeds can induce salt stress tolerance by modulating the antioxidant defenses [238]. The pre-treatment of barley seedlings with low $\mathrm{H}_{2} \mathrm{O}_{2}$ concentrations $(1$ or $5 \mu \mathrm{M})$ for two days induced tolerance upon $150 \mathrm{mM} \mathrm{NaCl}$ treatment. This response was parallel with the induction of three SOD isoenzymes and the decrease in $\mathrm{Na}^{+}$and $\mathrm{Cl}^{-}$uptake [239]. The treatment of wheat seedlings with very low $\mathrm{H}_{2} \mathrm{O}_{2}$ levels $(0.05 \mu \mathrm{M})$ improved its response to $150 \mathrm{mM} \mathrm{NaCl}$ in terms of plant growth (plant height, biomass and root length) coupled with a reduced $\mathrm{O}_{2}{ }^{-}$generation and lipid peroxidation levels and the increase of different antioxidant defenses [240]. More recently, [241] indicated that exogenous $\mathrm{H}_{2} \mathrm{O}_{2}$ could enhance salt tolerance in Vigna radiata L. plants by regulating the AsA and GSH metabolism.

AsA or vitamin C, as one of the most important antioxidants occurring in plants [242], plays an important role in ROS detoxification, providing protection and modulating other fundamental functions in plants under stress conditions [243-245]. AsA is also involved in key processes in plants, such as regulating photosynthetic capacity [246], flowering and senescence [247], and also as a co-factor for the biosynthesis and the signaling of several plant hormones (such as ethylene, JA, SA, ABA, and GA) under stressful environments [248]. AsA content and environmental conditions are linked in plants. As with other antioxidants, the variability of AsA content has been often considered relevant for explaining the different phenotype-dependent sensitivity against several stresses. It has been suggested that tolerance to stress is correlated with the capability of increasing AsA biosynthesis $[243,249,250]$. In this context, exogenous AsA is proposed to counteract the adverse effects of abiotic stress, when endogenous levels are not sufficient [251-253]. Thus, endogenous AsA can be increased by external treatments of AsA during different phases of development, applied on different organs (on roots, as a foliar spray or as seed priming), and in different types of crops, including vegetables, indeciduous fruits, oil-seeds, cereals and ornamental plants, among others. Exogenous application of AsA has been reported to enhance yield, growth and fruit quality [254-257], and more recently, it has been detected its potential effects on physiological responses of plants grown under abiotic stresses, such as salinity $[258,259]$, and counteracting the adverse effects of $\mathrm{NaCl}$ when wheat grains were soaked with AsA [260]. Effectiveness of AsA in a wide concentration range (from 0.1 to $34 \mathrm{mM}$ ) has been studied. For instance, the addition of $0.5 \mathrm{mM}$ AsA in tomato seedlings root medium attenuated the negative effects of salinity [261]. Particularly, $100 \mathrm{mg} / \mathrm{L}$ AsA applied on the root counteracted the adverse effects of salt stress on the growth of wheat under $150 \mathrm{mM} \mathrm{NaCl}$ [258], while $50-100 \mathrm{mg} / \mathrm{l} \mathrm{AsA}$ applied as foliar spray protected the photosynthetic machinery from the damaging effects of salt stress in halophytes [262].

In addition to increased ROS production, salinity produces nitrosative stress in plants mediated by the overproduction of some RNS, such as $\mathrm{NO}$ and peroxynitrite $\left(\mathrm{ONOO}^{-}\right)$[263,264], to which peroxisomes are the main source [263]. However, the pre-treatment with a NO-donor (such as sodium nitroprusside, SNP) can improve the response of plants to NaCl-induced damage [265-267]. SNP is a small bioactive signaling molecule which plays multiple roles in plant growth and 
development under normal or stressful conditions [268,269]. SNP ameliorates salt stress acting as a ROS scavenger throughout the formation of $\mathrm{ONOO}^{-}$, of less toxicity than $\mathrm{NO}$ [270] Moreover, SNP application stimulates proton-pump activity in the tonoplast, which in turn increases the $\mathrm{K}^{+} / \mathrm{Na}^{+}$ ratio [271]. Moreover, SNP regulates post-translational modifications of proteins involved in the cellular division [272]. The pre-treatment of Citrus aurantium L. plants with $100 \mu \mathrm{M}$ SNP or $10 \mathrm{mM}$ $\mathrm{H}_{2} \mathrm{O}_{2}$ for $48 \mathrm{~h}$ alleviated the physiological effects produced by $150 \mathrm{mM} \mathrm{NaCl}$ [265]. This response was linked to the regulation of protein carbonylation and S-nitrosylation of specific proteins [265]. Among the S-nitrosylated proteins there are involved in redox signaling and ROS scavenging, glycolysis, Calvin cycle, amino acids metabolism, photorespiration, and stress-related proteins. Some of the S-nitrosylated proteins were also subject of protein oxidation, including antioxidant proteins [(GST (glutathione S-transferase), SOD, peroxiredoxin), cytoskeleton proteins (tubulin, actin)], heat shock proteins (HSPs), translation and elongation factors, and metabolic proteins related to photosynthesis, glycolysis and the Krebs cycle [265]. The authors suggested the existence of a link between the different oxidative modifications events of proteins resulting from protein carbonylation or S-nitrosylation. They also pointed out that S-nitrosylation can prevent protein carbonylation events, thus, avoiding loss of function of proteins. In addition, S-nitrosylation of specific proteins can induce changes in protein function and/or structure. All these proteome changes, induced by $\mathrm{H}_{2} \mathrm{O}_{2}$ or $\mathrm{NO}$ treatments, can prepare the plants to cope with salt stress [265]. In soybean plants, the foliar application of $150 \mu \mathrm{M}$ SNP increased relative water content, chlorophyll and ABA levels, and improved stomatal control under stress conditions $(\mathrm{NaCl} 200 \mathrm{mM})$ in soybean plants [266]. Moreover, at short-term (6 and $12 \mathrm{~h})$, NO induced GST gene expression and GST enzyme activity under salt stress conditions. In addition, the pre-treatment of sunflower seeds with $250 \mu \mathrm{M}$ SNP demonstrated that NO can modulate the GSH content and its redox state via GR activity in sunflower seedlings subjected to $120 \mathrm{mM} \mathrm{NaCl}$ [267]. Thus, NO can act as a regulator of GSH metabolism, modulating the activity of GSH-dependent enzymes $[266,267,273]$

\subsection{Plant. Hormones (GA, SA)}

SA is a phenolic plant hormone widely distributed in plants, playing an important role in the regulation of different physiological processes, such as seed germination, vegetative growth, photosynthesis, respiration, thermogenesis, flower formation, fruit yield, seed production and senescence [274]. It is widely documented that exogenous SA treatments improved plant growth and seed germination under saline stress in different plant species [275-283]. In general, SA-treated plants showed lower $\mathrm{NaCl}$-induced symptoms and higher growth rate, chlorophyll contents, and photosynthetic capacity, as well as enhanced antioxidant capacity in relation to non-treated plants [275-283]. Hence, SA induces genes encoding antioxidants, chaperones and secondary metabolites, among others. However, evidence linking exogenous SA and resistance against salt stress remains controversial. In this sense, [284] observed that SA negatively affects the response of pea plants to $\mathrm{NaCl}$ stress, although low SA levels led to the induction of a pathogenesis-related protein $(P R-1 b)$ gene in leaves from $\mathrm{NaCl}$-stressed pea plants. The induction of $P R-1 b$ gene could be an adaptive response in order to prevent an opportunistic fungal or bacterial infection in a weakness situation [284]. In this sense, the precise mechanisms of SA in the response of plants to salinity have to be unraveled, since SA effect seems to be dependent on the concentration, the plant species, the application mode, the physiological state of the plant during the application, as well as the level of salinity and the exposure time to $\mathrm{NaCl}$. In Arabidopsis, SA has been reported to play a dual role: At low concentration, it induced antioxidant defenses, but excess application induced programmed cell death [285].

GA are a group of plant hormones involved in many developmental processes, such as seed germination, plant growth, flowering and fruit development [286]. Different studies showed that exogenous GA treatments can reverse the negative effects of salt stress. Kaur et al. [287] reported that low concentrations of exogenous $\mathrm{GA}_{3}(6 \mu \mathrm{M})$ promoted seed germination and seedling growth of chickpeas under $\mathrm{NaCl}$ stress $(75 \mathrm{mM})$. These authors also observed that $\mathrm{GA}_{3}$ treatment increased $\alpha$-amylase 
activity, which enhanced the starch mobilization, thus, leading to a better seedling growth [287]. Exogenous-applied $\mathrm{GA}_{3}$ alleviated the effects of salt stress in tomato plants through a partial stomatal closure that reduced the upload of toxic ions to the shoots, and as a result, the appearance of toxicity symptoms [288]. Application of $\mathrm{GA}_{3}$ also enabled the maintenance of photosynthetic capacity under salt stress by mitigating the salt-induced reduction of chlorophyll content [289]. Several studies have shown the positive effect of $\mathrm{GA}_{3}$ in alleviating the toxic effects of $\mathrm{NaCl}$ on rice growth [290-293]. Exogenous application of $50 \mu \mathrm{M} \mathrm{GA}_{3}$ improved the seed germination and early seedling growth of Arabidopsis in the presence of $100 \mathrm{mM} \mathrm{NaCl}$. These positive effects of $\mathrm{GA}_{3}$ was accompanied by an increase of endogenous SA levels, suggesting that the improved response of GA-treated plants under salinity conditions can be mediated by the modulation of SA levels [294].

\section{Conclusions}

Upon salt stress, typical effects in the plant are reduction of fresh weight, the appearance of chlorosis and necrosis and altered metabolic processes, such as photosynthesis, phytohormone regulation, respiration, nutrient balance, ion toxicity, and protein biosynthesis, which are generally mediated by oxidative stress. In recent years, the application of phytoprotectants, such as those of microbial origin (arbuscular mycorrhizal fungi and plant growth-promoting rhizobacteria), osmoprotectants, melatonin, phytohormones and antioxidant metabolism-related compounds has proven to be a sustainable agronomic practice to obtain plants more resistant to salinity avoiding losses in crop yields. Figure 1 shows an overview of factors involved in phytoprotectants application, their role in the plant and the output obtained from an agro-economical point of view. Beyond the phytoprotectant nature, other factors, such as plant or phenotype sensitivity towards a specific phytoprotectant, application form and targeted plant organ determine their applicability. Herein, efforts from academic and industrial sectors should focus on defining the conditions and associations providing higher benefits. Overall, phytoprotectants mode of action converge into the management of water and nutrient balance, increased photosynthesis efficiency and activation of enzymatic and non-enzymatic antioxidant defenses that leads to an alleviation of the oxidative stress produced in response to salinity. As a result, increased crop yield and crop quality are achieved, which in turn positively impact food security and consumer acceptance of the product. In this sense, improved tolerance of the plant to salt stress avoids growth abnormalities and provides greener leafy vegetables, which determine visual consumer preferences. Table 1 shows the literature collected in this review concerning the exogenous application of phytoprotectants, which resulted in beneficial effects in the plant. The type of phytoprotectant, application mode and dose, plant species, and major effects in the plant in terms of physiological changes and phenotype are listed. 


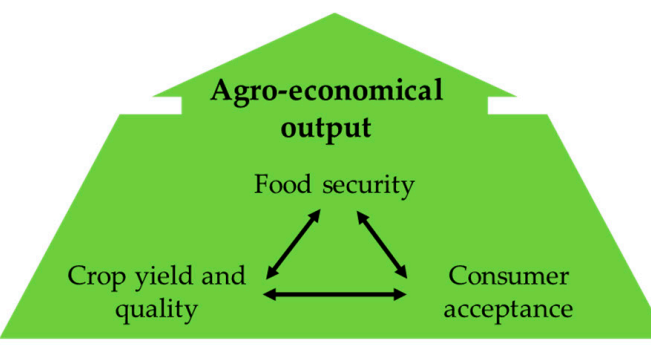

Improved physiological processes

Nutrient balance (selective nutrient availability and uptake)

Water balance (osmotic adjustment, hydraulic conductivity)

Photosynthesis (chlorophyll synthesis, photosystem efficiency)

Antioxidant defences (increased antioxidants and stress alleviation)

\section{Applicability}

Phenological state of the plant (seed, seedling, adult plant)

Dose (concentration, timing, species-dependent sensitivity, soil structure)

Form (seed treatment, seedling dip, soil application, foliar spray, fruit spray)

\section{Phytoprotectant nature}

Microbial origin (arbuscular mycorrhizal fungi and plant growth-promoting rhizobacteria)

Nitrogen-containing compounds (osmoprotectans and melatonin)

Antioxidant metabolisms-related compounds (AsA, $\mathrm{H}_{2} \mathrm{O}_{2}, \mathrm{RNS}$ )

Phytohormones (GA, SA)

Figure 1. Overview of factors involved in phytoprotectants application, their role in the plant and the output obtained from an agro-economical point of view. Phytoprotectants of diverse nature (arbuscular mycorrhizal fungi, plant growth-promoting rhizobacteria, nitrogen-containing compound, and antioxidant metabolisms-related compounds) are applied to plants to overcome the adverse effects of salt stress. Their applicability is determined by the phenological state of the plant, the dose of the phytoprotectant, the targeted plant organ and the application form. Herein, finding a suitable interaction between phyoprotectant and plant species or phenotype is key. The amelioration of salt stress impact in the plant by phytoprotectants is commonly achieved through management of water and nutrient balance, increased photosynthesis efficiency and activation of enzymatic and non-enzymatic antioxidant defenses. Consequently, increased crop yield, resilience and quality are achieved, which in turn report economic benefits through higher food security—improved productivity and land use —and consumer preferences on a higher quality product. AsA: ascorbic acid; GA: gibberellic acid; RNS: reactive nitrogen species; $S A$ : salicylic acid. 
Table 1. Studies showing beneficial responses of plants of agronomic interest to phytoprotectants applications. The specific phytoprotectant, application mode and dose, plant species, and major effects in the plant in terms of physiological changes and phenotype are listed.

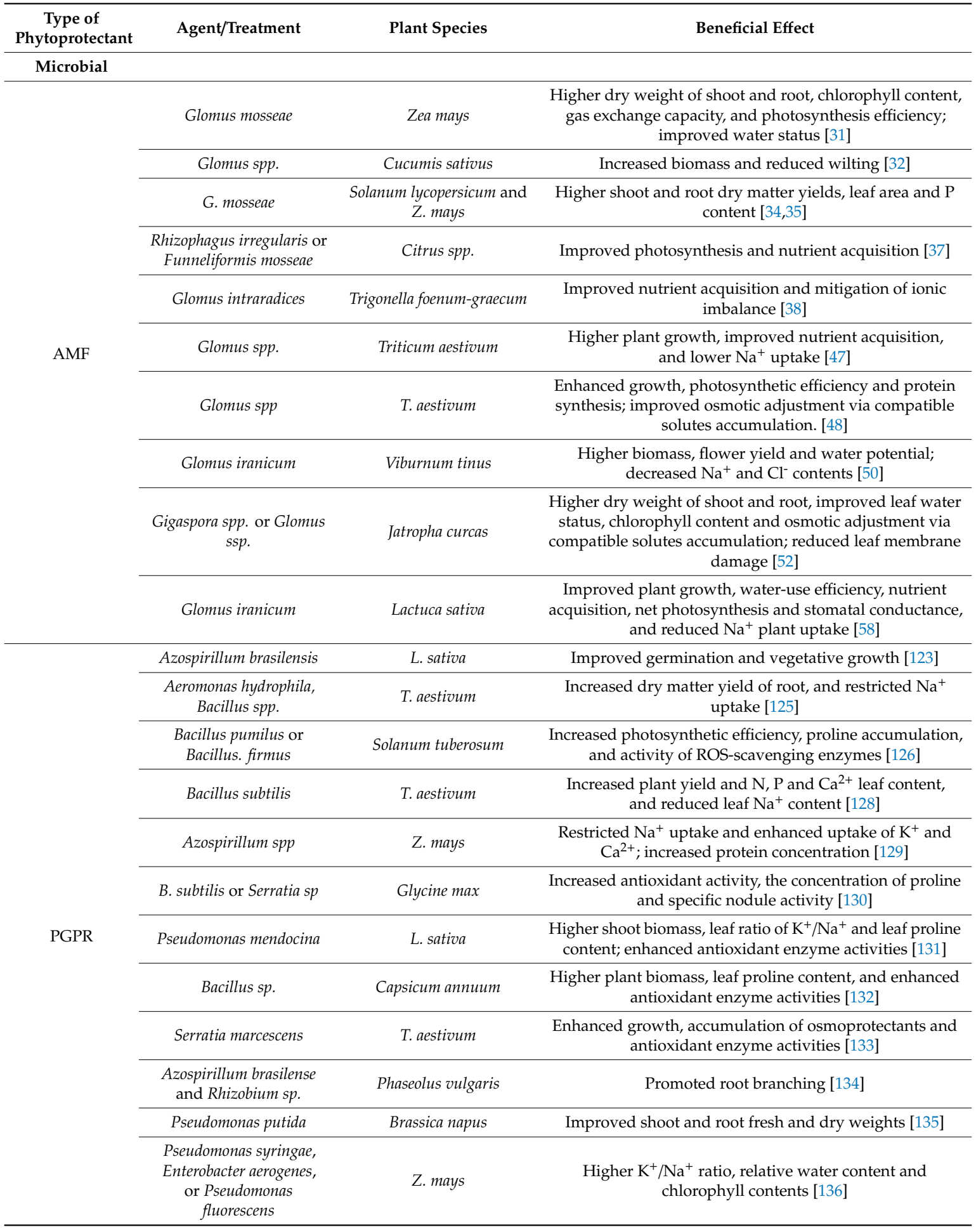


Table 1. Cont.

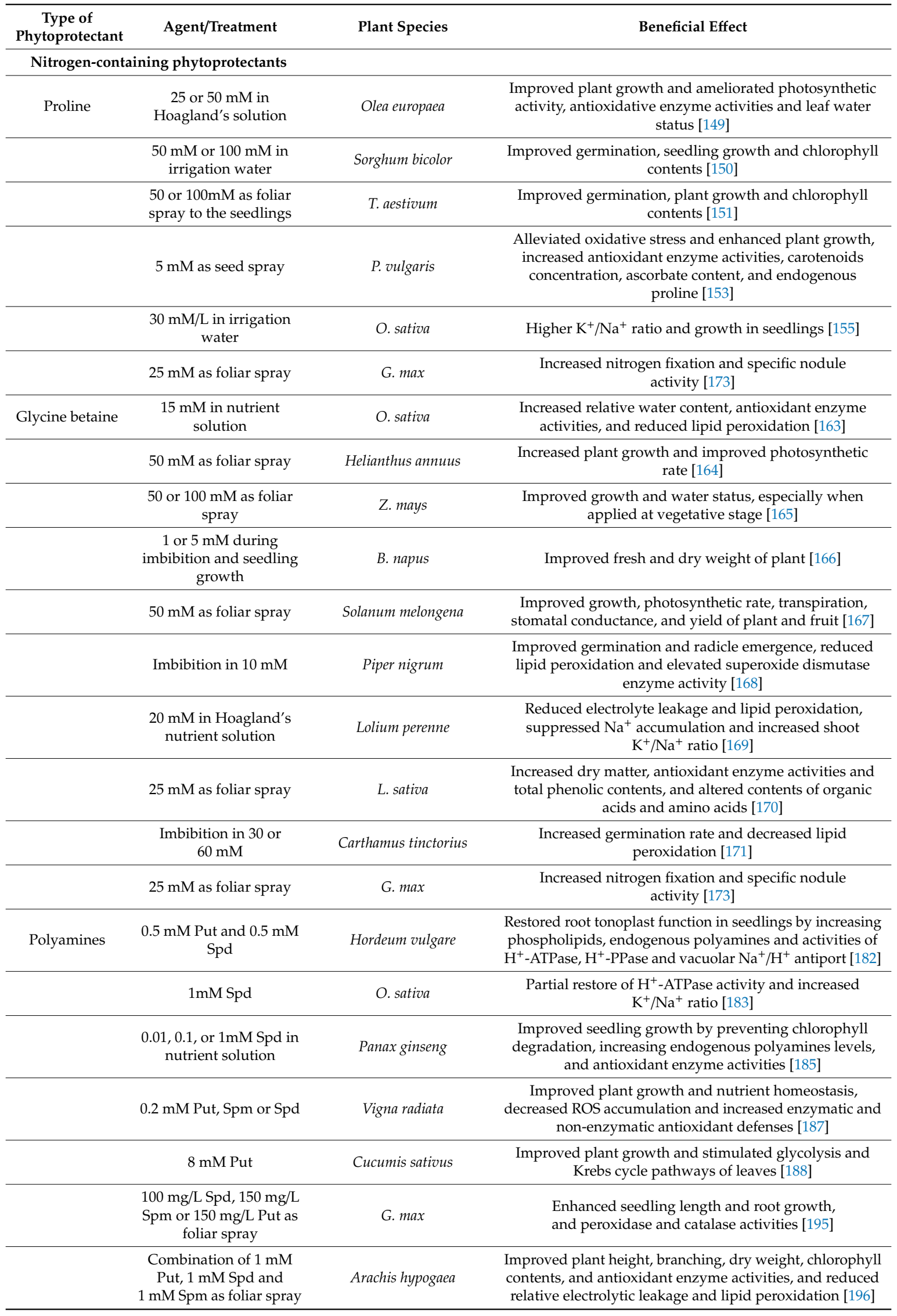


Table 1. Cont

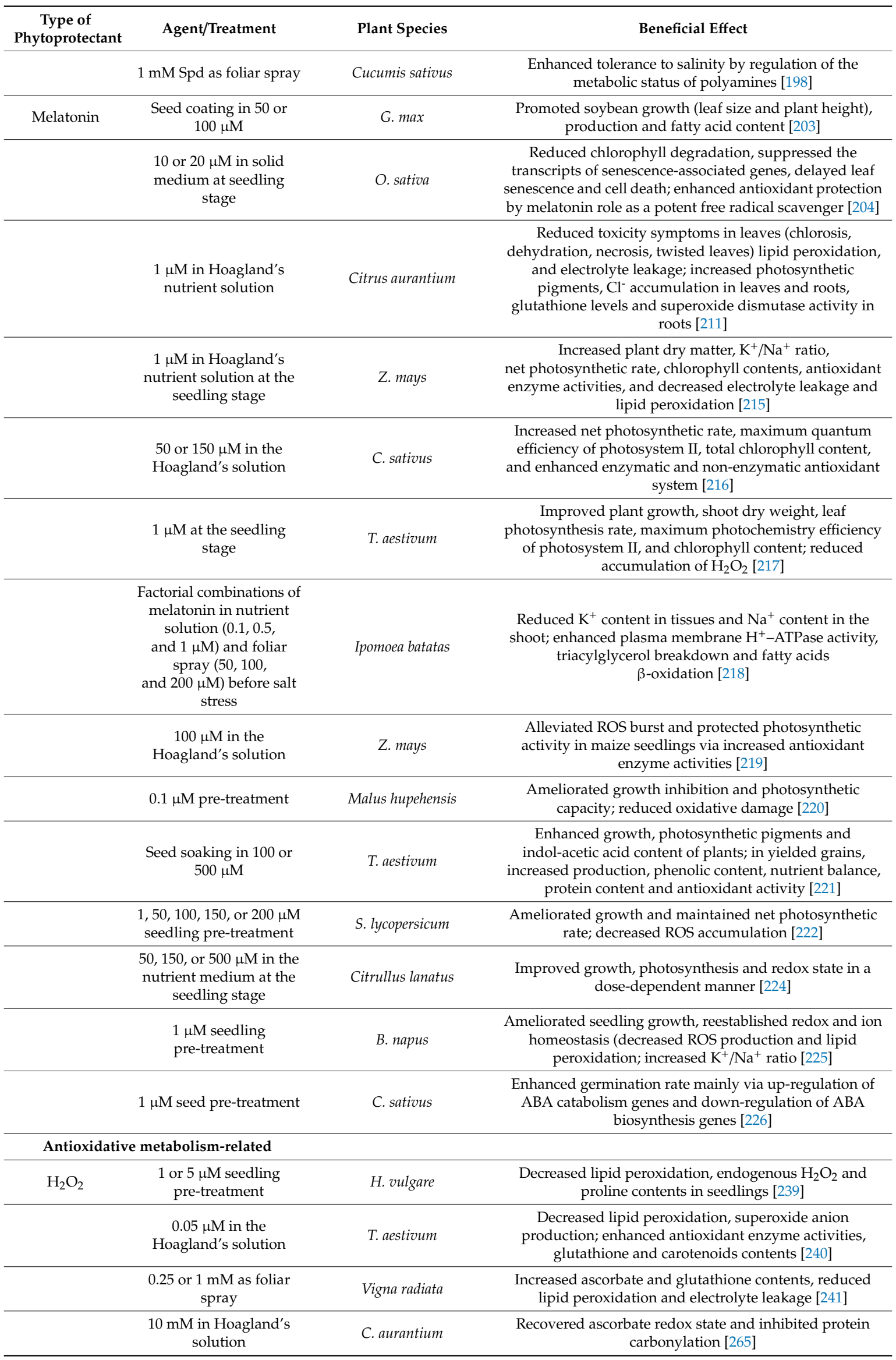


Table 1. Cont

\begin{tabular}{|c|c|c|c|}
\hline $\begin{array}{c}\text { Type of } \\
\text { Phytoprotectant }\end{array}$ & Agent/Treatment & Plant Species & Beneficial Effect \\
\hline \multirow[t]{4}{*}{ Ascorbate } & $150 \mathrm{ppm}$ as foliar spray & Pennisetum glaucum & $\begin{array}{l}\text { In combination with zinc sulfate increased the plant height } \\
\text { and total plant biomass [257] }\end{array}$ \\
\hline & $\begin{array}{l}50 \text { or } 150 \mathrm{mg} / \mathrm{L} \text { in } \\
\text { nutrient solution }\end{array}$ & T. aestivum & $\begin{array}{l}\text { Enhanced growth, endogenous ascorbate level, catalase } \\
\text { activity, photosynthetic capacity and leaf } \mathrm{K}^{+} \text {and } \mathrm{Ca}^{2+} \\
\text { contents [258] }\end{array}$ \\
\hline & Seed soaking in $0.6 \mathrm{mM}$ & T. aestivum & $\begin{array}{l}\text { Decreased } \mathrm{Na}^{+} \text {and increased } \mathrm{K}^{+}, \mathrm{Mg}^{2+} \text { and } \mathrm{Ca}^{2+} \text { in the } \\
\text { different organs, increased shoot and root starch [260] }\end{array}$ \\
\hline & $\begin{array}{l}0.5 \mathrm{mM} \text { in the nutrient } \\
\text { medium }\end{array}$ & S. lycopersicum & $\begin{array}{l}\text { Reduced lipid peroxidation and facilitated seedling } \\
\text { recovery and survival after stress [261] }\end{array}$ \\
\hline \multirow{4}{*}{$\begin{array}{l}\text { Sodium } \\
\text { nitroprusside }\end{array}$} & $\begin{array}{l}150 \mu \mathrm{M} \text { sprayed to } \\
\text { seedlings }\end{array}$ & G. $\max$ & $\begin{array}{c}\text { Reduced leaf chlorotic damage, improved stomatal control, } \\
\text { increased chlorophyll content, ABA content, GST activity } \\
\text { and root water content [266] }\end{array}$ \\
\hline & $\begin{array}{l}250 \mu \mathrm{M} \text { in Hoagland's } \\
\text { solution to seedlings }\end{array}$ & H. annuus & $\begin{array}{l}\text { Decreased ROS accumulation and stimulated melatonin } \\
\text { accumulation [267] }\end{array}$ \\
\hline & $\begin{array}{l}50 \mu \mathrm{M} \text { in Hoagland's } \\
\text { solution }\end{array}$ & S. lycopersicum & $\begin{array}{l}\text { Up-regulated antioxidant metabolism, osmolyte synthesis, } \\
\text { and metabolite accumulation [269] }\end{array}$ \\
\hline & $\begin{array}{l}0.03 \text { or } 0.06 \mathrm{~g} / \mathrm{L} \text { as foliar } \\
\text { spray }\end{array}$ & P. vulgaris & $\begin{array}{l}\text { Increased plant dry weight, carotenoids and ABA contents, } \\
\text { pod diameter and fiber percentage [270] }\end{array}$ \\
\hline \multirow{7}{*}{ Salycilic acid } & $\begin{array}{l}100 \mu \mathrm{M} \text { pre-treatment in } \\
\text { hydroponic medium }\end{array}$ & S. lycopersicum & $\begin{array}{c}\text { Reduced leaf } \mathrm{K}^{+} \text {content and leaf water potential; } \\
\text { triggered ABA accumulation and free putrescine and } \\
\text { spermine levels [277] }\end{array}$ \\
\hline & $\begin{array}{l}0.5 \text { or } 1 \mathrm{mM} \text { as foliar } \\
\text { spray }\end{array}$ & Gerbera jamesonii & $\begin{array}{c}\text { Reduced lipid peroxidation and electrolyte leakage; } \\
\text { increased superoxide dismutase and peroxidase } \\
\text { activities [278] }\end{array}$ \\
\hline & $50 \mu \mathrm{M}$ during imbibition & A. thaliana & $\begin{array}{l}\text { Ameliorated germination by reducing oxidative } \\
\text { damage [279] }\end{array}$ \\
\hline & $\begin{array}{l}100 \mu \mathrm{M} \text { sprayed on } \\
\text { seedlings }\end{array}$ & B. napus & $\begin{array}{l}\text { Increased ascorbate and glutathione contents, glutathione } \\
\text { redox status and antioxidant enzymes activities [280] }\end{array}$ \\
\hline & $100 \mu \mathrm{M}$ as foliar spray & Gossypium hirsutum & $\begin{array}{l}\text { Increased growth rate, net photosynthetic rate, } \\
\text { transpiration rate and reactive oxygen species-scavenging } \\
\text { enzymes activities; reduced } \mathrm{H}_{2} \mathrm{O}_{2} \text { accumulation in } \\
\text { seedlings, leaf electrolyte leakage; alleviated inhibition of } \\
\text { plasma membrane } \mathrm{H}^{+} \text {-ATPase [281] }\end{array}$ \\
\hline & $0.5 \mathrm{mM}$ as foliar spray & Brassica juncea & $\begin{array}{l}\text { Improved growth, photosynthesis, activity of enzymes of } \\
\text { ascorbate-glutathione cycle and glutathione content [282] }\end{array}$ \\
\hline & $\begin{array}{l}0.1 \text { or } 0.5 \mathrm{mM} \\
\text { pre-treatment in the } \\
\text { growth medium }\end{array}$ & Medicago sativa & $\begin{array}{l}\text { Alleviated plant growth and photosynthetic capacity, } \\
\text { increased } \mathrm{H}_{2} \mathrm{O}_{2} \text {-scavenging enzyme activities [283] }\end{array}$ \\
\hline
\end{tabular}


Table 1. Cont

\begin{tabular}{|c|c|c|c|}
\hline $\begin{array}{c}\text { Type of } \\
\text { Phytoprotectant }\end{array}$ & Agent/Treatment & Plant Species & Beneficial Effect \\
\hline & $\begin{array}{l}10 \text { ppm pre-treatment as } \\
\text { foliar spray }\end{array}$ & O. sativa & $\begin{array}{l}\text { Increased growth; reduced net accumulation of } \mathrm{Na}^{+} \text {and } \\
\mathrm{Cl}^{-} \text {maintained high level leaf } \mathrm{K}^{+} \text {accumulation [291] }\end{array}$ \\
\hline & $\begin{array}{l}100 \mu \mathrm{M} \text { during } \\
\text { germination }\end{array}$ & O. sativa & Ameliorated germination and growth inhibition [292] \\
\hline & $\begin{array}{l}10 \mu \mathrm{M} \text { pre-treatment in } \\
\text { hydroponic medium }\end{array}$ & O. sativa & $\begin{array}{l}\text { Up-regulation of lipid biosynthesis and increased } \\
\text { chlorophyll concentration [293] }\end{array}$ \\
\hline & $50 \mu \mathrm{m}$ during imbibition & A. thaliana & $\begin{array}{l}\text { Improved germination and seedling establishment; } \\
\text { increased salicylic acid levels [294] }\end{array}$ \\
\hline
\end{tabular}

AMF, arbuscular mychorrhizal fungi; PGPR, plant growth-promoting rhizobacteria; Put, putrescine; Spd, spermidine; Spm, spermine.

Further investigation should be conducted for understanding the physiological and molecular mechanisms involved during the action of phytoprotectants on plants and their effectiveness. In addition, aspects, such as phytoprotectant evaluation under multiple environmental stressors, or innovative approaches, such as the combination of phytoprotectants and intercropping systems should be taken into account. As our knowledge expands, more commercial formulations may be designed, accomplishing more sustainable agrarian systems.

Author Contributions: Conceptualization: J.R.A.-M., C.P., J.A.H. and G.B.-E.; writing-original draft preparation: all authors; writing - review and editing: all authors; Table and Figure: G.B.-E. and J.R.A.-M. All authors have read and agreed to the published version of the manuscript.

Funding: This work was supported by "Fundación Séneca" of the Agency of Science and Technology of the Region of Murcia (grant numbers 20405/SF/17 and 19903/GERM/1), RTI2018-093997-B-100 (MCIU/AEI/FEDER, UE project).

Acknowledgments: The first author wants to thank "Banco Santander" for its financial support through the UCAM-Santander Chair.

Conflicts of Interest: The authors declare no conflict of interest.

\section{Abbreviations}

$\begin{array}{ll}\text { ABA } & \text { abscisic acid } \\ \text { AMF } & \text { arbuscular mychorrhizal fungi } \\ \text { APX } & \text { ascorbate peroxidase } \\ \text { AsA } & \text { ascorbic acid } \\ \text { BADH } & \text { betaine aldehyde dehydrogenase } \\ \text { Cad } & \text { cadaverine } \\ \text { CAT } & \text { catalase } \\ \text { CMO } & \text { choline monooxygenase } \\ \text { DHAR } & \text { dehydroascorbate reductase } \\ \text { dS } & \text { deciSiemens } \\ \text { FAO } & \text { food and agricultural organization } \\ \text { GA } & \text { gibberellins } \\ \text { GB } & \text { glycine betaine } \\ \text { GPX } & \text { glutathione peroxidase } \\ \text { GR } & \text { glutathione reductase } \\ \text { GSH } & \text { glutathione } \\ \text { GST } & \text { glutathione S-transferase } \\ \text { HSP } & \text { heat shock protein } \\ \text { IST } & \text { induced systemic tolerance } \\ \text { JA } & \text { jasmonic acid } \\ \text { NAD } & \text { nicotinamide adenine dinucleotide } \\ \text { NADP } & \text { nicotinamide adenine dinucleotide phosphate }\end{array}$




$\begin{array}{ll}\text { PA } & \text { polyamines } \\ \text { PDH } & \text { proline dehydrogenase } \\ \text { PGPR } & \text { plant growth-promoting rhizobacteria } \\ \text { POD } & \text { peroxidase } \\ \text { Pro } & \text { proline } \\ \text { Put } & \text { putrescine } \\ \text { ROS } & \text { reactive oxygen species } \\ \text { RNS } & \text { reactive nitrogen species } \\ \text { SA } & \text { salicylic acid } \\ \text { SAMDC } & \text { S-adenosylmethionine decarboxylase } \\ \text { SNP } & \text { sodium nitroprusside } \\ \text { SOD } & \text { superoxide dismutase } \\ \text { Spd } & \text { spermidine } \\ \text { Spm } & \text { spermine } \\ \text { WWTP } & \text { wastewater treatment plants }\end{array}$

\section{References}

1. Gray, S.B.; Brady, S.M. Plant developmental responses to climate change. Dev. Biol. 2016, 419, 64-77. [CrossRef] [PubMed]

2. FAO. The State of Food and Agriculture: Climate Change, Agriculture and Food Security; FAO: Rome, Italy, 2016; pp. 1-174.

3. Cramer, G.R.; Urano, K.; Delrot, S.; Pezzotti, M.; Shinozaki, K. Effects of abiotic stress on plants: A systems biology perspective. BMC Plant Biol. 2011, 11, 163. [CrossRef] [PubMed]

4. Hasanuzzaman, M.; Nahar, K.; Fujita, M. Plant response to salt stress and role of exogenous protectants to mitigate salt-induced damages. In Ecophysiology and Responses of Plants under Salt Stress; Ahmad, P., Azooz, M.M., Prasad, M.N.V., Eds.; Springer: New York, NY, USA, 2013; pp. 25-87.

5. Rengasamy, P. Soil processes affecting crop production in salt-affected soils. Funct. Plant Biol. 2010, 37, 613-620. [CrossRef]

6. Pedrero, F.; Alarcón, J.J. Effects of treated wastewater irrigation on lemon trees. Desalination 2009, 246, 631-639. [CrossRef]

7. Valdés, R.; Miralles, J.R.; Ochoa, J.; Sánchez-Blanco, M.J.; Bañón, S. Saline reclaimed wastewater can be used to produce potted weeping fig with minimal effects on plant quality. Span. J. Agric. Res. 2012, 10, 1167-1175. [CrossRef]

8. Bañon, S.; Miralles, J.; Ochoa, J.; Sánchez-Blanco, M.J. The effect of salinity and high boron on growth, photosynthetic activity and mineral contents of two ornamental shrubs. Hort. Sci. 2012, 39, 188-194. [CrossRef]

9. Acosta-Motos, J.R.; Hernández, J.A.; Álvarez, S.; Barba-Espín, G.; Sánchez-Blanco, M.J. The long-term resistance mechanisms, critical irrigation threshold and relief capacity shown by Eugenia myrtifolia plants in response to saline reclaimed water. Plant Physiol. Bioch. 2017, 111, 244-256. [CrossRef]

10. Acosta-Motos, J.R.; Ortuño, M.F.; Álvarez, S.; Hernández, J.A.; Sánchez-Blanco, M.J. The use of reclaimed water is a viable and safe strategy for the irrigation of myrtle plants in a scenario of climate change. Water Supply 2019, 19, 1741-1747. [CrossRef]

11. Romero-Trigueros, C.; Bayona Gambín, J.M.; Nortes Tortosa, P.A.; Alarcón Cabañero, J.J.; Nicolás, E.N. Determination of Crop Water Stress index by infrared thermometry in grapefruit trees irrigated with saline reclaimed water combined with deficit irrigation. Remote Sens. 2019, 11, 757. [CrossRef]

12. Romero-Trigueros, C.; Vivaldi, G.A.; Nicolás, E.N.; Paduano, A.; Salcedo, F.P.; Camposeo, S. Ripening Indices, Olive Yield and Oil Quality in Response to Irrigation with Saline Reclaimed Water and Deficit Strategies. Front. Plant Sci. 2019, 10, 1243. [CrossRef]

13. Vivaldi, G.A.; Camposeo, S.; Lopriore, G.; Romero-Trigueros, C.; Salcedo, F.P. Using saline reclaimed water on almond grown in Mediterranean conditions: Deficit irrigation strategies and salinity effects. Water Supply 2019, 19, 1413-1421. [CrossRef]

14. Larcher, W. Physiological Plant Ecology, 4th ed.; Springer: Berlin, Germany, 2003; pp. 416-428. 
15. Green, T.G.A.; Sancho, L.G.; Pintado, A.; Saco, D.; Martín, S.; Arróniz-Crespo, M.; Casermeiro, M.A.; Caravaca, M.T.; Cameron, S.; Rozzi, R. Sodium chloride accumulation in glycophyte plants with cyanobacterial symbionts. AoB Plants 2017, 9, plx053. [CrossRef] [PubMed]

16. Van Beek, C.; Tóth, G. Risk Assessment Methodologies of Soil Threats in Europe; JRC Scientific and Policy Reports EUR, Office for Official Publication of the European Communities: Luxembourg, Luxembourg, 2012; pp. 1-97.

17. Isayenkov, S.V.; Maathuis, F.J.M. Plant Salinity Stress: Many Unanswered Questions Remain. Front. Plant Sci. 2019, 10, 80. [CrossRef] [PubMed]

18. Hernández, J.A.; Corpas, F.J.; Gómez, M.; del Río, L.A.; Sevilla, F. Salt induced oxidative stress mediated by activated oxygen species in pea leaf mitochondria. Physiol. Plant. 1993, 89, 103-110. [CrossRef]

19. Hernández, J.A.; Olmos, E.; Corpas, F.J.; Sevilla, F.; del Río, L.A. Salt-induced oxidative stress in chloroplast of pea plants. Plant Sci. 1995, 105, 151-167. [CrossRef]

20. Hernández, J.A.; Ferrer, M.A.; Jiménez, A.; Barceló, A.R.; Sevilla, F. Antioxidant systems and $\mathrm{O}_{2}{ }^{-\cdots} / \mathrm{H}_{2} \mathrm{O}_{2}$ production in the apoplast of pea leaves. Its relation with salt-induced necrotic lesions in minor veins. Plant Physiol. 2001, 127, 817-831. [CrossRef]

21. Parida, A.K.; Das, A.B. Salt tolerance and salinity effects on plants: A review. Ecotoxicol. Environ. Saf. 2005, 60, 324-349. [CrossRef]

22. Munns, R.; Tester, M. Mechanisms of salinity tolerance. Ann. Rev. Plant Biol. 2008, 59, 651-681. [CrossRef]

23. Ashraf, M.; Harris, P.J.C. Photosynthesis under stressful environments: An overview. Photosynthetica 2013, 51, 163-190. [CrossRef]

24. Acosta-Motos, J.R.; Ortuño, M.F.; Bernal-Vicente, A.; Diaz-Vivancos, P.; Sánchez-Blanco, M.J.; Hernandez, J.A. Plant Responses to Salt Stress: Adaptive Mechanisms. Agronomy 2017, 7, 18. [CrossRef]

25. Smith, S.E.; Read, D.J. Mycorrhizal Symbiosis, 3rd ed.; Academic Press: New York, NY, USA, 2008; p. 800.

26. Khan, A.G. Role of soil microbes in the rhizospheres of plants growing on trace metal contaminated soils in phytoremediation. J. Trace Elem. Med. Biol. 2005, 18, 355-364. [CrossRef] [PubMed]

27. Augé, R.M. Water relations, drought and vesicular-arbuscular mycorrhizal symbiosis. Mycorrhiza 2001, 11, 3-42. [CrossRef]

28. Fernández, F.; Juárez, J. Procedimiento de obtención de un agente micorrizógeno. Solicitud de Patente Invención n ${ }^{\circ}$ 201130566. ES2364684A1, 2011.

29. Juniper, S.; Abbott, L.K. Soil salinity delays germination and limits growth of hyphae from propagules of arbuscular mycorrhizal fungi. Mycorrhiza 2006, 16, 371-379. [CrossRef] [PubMed]

30. Giri, B.; Kapoor, R.; Mukerji, K.G. Improved tolerance of Acacia nilotica to salt stress by arbuscular mycorrhiza, Glomus fasciculatum may be partly related to elevated K/Na ratios in root and shoot tissues. Microb. Ecol. 2007, 54, 753-760. [CrossRef]

31. Sheng, M.; Tang, M.; Chen, H.; Yang, B.; Zhang, F.; Huang, Y. Influence of arbuscular mycorrhizae on photosynthesis and water status of maize plants under salt stress. Mycorrhiza 2008, 18, 287-296. [CrossRef]

32. Rosendahl, C.N.; Rosendahl, S. Influence of vesicular-arbuscular mycorrhizal fungi (Glomus SPP.) on the response of cucumber (Cucumis sativus L.) to salt stress. Environ. Exp. Bot. 1991, 31, 313-318. [CrossRef]

33. Ruiz-Lozano, J.M.; Azcon, R. Mycorrhizal colonization and drought stress as factors affecting nitrate reductase activity in lettuce plants. Agric. Ecosyst. Environ. 1996, 60, 175-181. [CrossRef]

34. Al-Karaki, G.; Hammad, R.; Rusan, M. Response of two tomato cultivars differing in salt tolerance to inoculation with mycorrhizal fungi under salt stress. Mycorrhiza 2001, 11, 43-47. [CrossRef]

35. Feng, G.; Zhang, F.; Li, X.; Tian, C.; Tang, C.; Rengel, Z. Improved tolerance of maize plants to salt stress by arbuscular mycorrhiza is related to higher accumulation of soluble sugars in roots. Mycorrhiza 2002, 12, 185-190.

36. Giri, B.; Kapoor, R.; Mukerji, K.G. Influence of arbuscular mycorrhizal fungi and salinity on growth, biomass and mineral nutrition of Acacia auriculiformis. Biol. Fert. Soils 2003, 38, 170-175. [CrossRef]

37. Navarro, J.M.; Pérez-Tornero, O.; Morte, A. Alleviation of salt stress in citrus seedlings inoculated with arbuscular mycorrhizal fungi depends on the rootstock salt tolerance. J. Plant Physiol. 2014, 171, 76-85. [CrossRef] [PubMed]

38. Evelin, H.; Giri, B.; Kapoor, R. Contribution of Glomus intraradices inoculation to nutrient acquisition and mitigation of ionic imbalance in NaCl-stressed Trigonella foenum-graecum. Mycorrhiza 2012, 22, $203-217$. [CrossRef] [PubMed] 
39. Porcel, R.; Aroca, R.; Ruíz-Lozano, J.M. Salinity stress alleviation using arbuscular mycorrhizal fungi. A review. Agron. Sustain. Dev. 2012, 32, 181-200. [CrossRef]

40. Augé, R.M.; Toler, H.D.; Saxton, A.M. Arbuscular mycorrhizal symbiosis alters stomatal conductance of host plants more under drought than under amply watered conditions: A meta-analysis. Mycorrhiza 2015, 25, 13-24. [CrossRef]

41. Kumar, A.; Dames, J.F.; Gupta, A.; Sharma, S.; Gilbert, J.A.; Ahmad, P. Current developments in arbuscular mycorrhizal fungi research and its role in salinity stress alleviation: A biotechnological perspective. Crit. Rev. Biotechnol. 2015, 35, 461-474. [CrossRef]

42. Kapoor, R.; Sharma, D.; Bhatnagar, A.K. Arbuscular mycorrhizae in micropropagation systems and their potential applications. Sci. Hort. 2008, 116, 227-239. [CrossRef]

43. Hameed, A.; Dilfuza, E.; Abd-Allah, E.F.; Hashem, A.; Kumar, A.; Ahmad, P. Salinity stress and arbuscular mycorrhizal symbiosis in plants. In Use of Microbes for the Alleviation of Soil Stresses; Miransari, M., Ed.; Springer: New York, NY, USA, 2014; Volume 1, pp. 139-159.

44. Zhang, Z.; Wang, Q.; Wang, H.; Nie, S.; Liang, Z. Effects of soil salinity on the content, composition, and ion binding capacity of glomalin-related soil protein (GRSP). Sci. Total Environ. 2017, 581, 657-665. [CrossRef]

45. Zou, Y.N.; Srivastava, A.K.; Ni, Q.D.; Wu, Q.S. Disruption of mycorrhizal extraradical mycelium and changes in leaf water status and soil aggregate stability in rootbox-grown trifoliate orange. Front. Microbiol. 2015, 6, 203. [CrossRef]

46. Lehmann, A.; Rillig, M.C. Arbuscular mycorrhizal contribution to copper, manganese and iron nutrient concentrations in crops: A metaanalysis. Soil Biol. Biochem. 2015, 81, 147-158. [CrossRef]

47. Mardukhi, B.; Rejali, F.; Daei, G.; Ardakani, M.R.; Malakouti, M.J.; Miransari, M. Arbuscular mycorrhiza enhance nutrient uptake in different wheat genotypes at high salinity levels under field and greenhouse conditions. Cr. Biol. 2011, 334, 564-571. [CrossRef]

48. Talaat, N.B.; Shawky, B.T. Protective effects of arbuscular mycorrhizal fungi on wheat (Triticum aestivum L.) plants exposed to salinity. Environ. Exp. Bot. 2014, 98, 20-31. [CrossRef]

49. Asrar, A.A.; Abdel-Fattah, G.M.; Elhindi, K.M.; Abdel-Salam, E.M. The impact of arbuscular mychorrhizal fungi in improving growth, flower yield and tolerance of kalanchoe (Kalanchoe blossfeldiana Poelin) plants grown in NaCl-stress conditions. J. Food Agri. Environ. 2014, 12, 105-112.

50. Gómez-Bellot, M.J.; Ortuño, M.F.; Nortes, P.A.; Vicente-Sánchez, J.; Martín, F.F.; Bañón, S.; Sánchez-Blanco, M.J. Protective effects of Glomus iranicum var. tenuihypharum on soil and Viburnum tinus plants irrigated with treated wastewater under field conditions. Mycorrhiza 2015, 25, 399-409. [CrossRef] [PubMed]

51. Asghari, H.R.; Amerian, M.R.; Gorbani, H. Soil salinity affects arbuscular mycorrhizal colonization of halophytes. Pak. J. Biol. Sci. 2008, 11, 1909-1915. [CrossRef] [PubMed]

52. Kumar, A.; Sharma, S.; Mishra, S. Influence of arbuscular mycorrhizal (AM) fungi and salinity on seedlings growth, solute accumulation, and mycorrhizal dependency of Jatropha curcas L. J. Plant Growth Regul. 2010, 29, 297-306. [CrossRef]

53. Zhong, Q.H.; Chao, X.H.; Zhi, B.Z.; Zhi, R.Z.; Huai, S.W. Changes in antioxidative enzymes and cell membrane osmosis in tomato colonized by arbuscular mycorrhizae under $\mathrm{NaCl}$ stress. Colloids Surf. B Biointerfaces 2007, 59, 128-133.

54. Evelin, H.; Kapoor, R.; Giri, B. Arbuscular mycorrhizal fungi in alleviation of salt stress: A review. Ann. Bot. 2009, 104, 1263-1280. [CrossRef]

55. Alguacil, M.M.; Hernández, J.A.; Caravaca, F.; Portillo, B.; Roldán, A. Antioxidant enzyme activities in shoots from three mycorrhizal shrub species afforested in a degraded semi-arid soil. Physiol. Plant. 2003, 118, 562-570. [CrossRef]

56. Corkidi, L.; Rowland, D.L.; Johnson, N.C.; Allen, E.B. Nitrogen fertilization alters the functioning of arbuscular mycorrhizas at two semiarid grasslands. Plant Soil 2002, 240, 299-310. [CrossRef]

57. Chen, Y.L.; Zhang, X.; Ye, J.S.; Han, H.Y.; Wan, S.Q.; Chen, B.D. Six-year fertilization modifies the biodiversity of arbuscular mycorrhizal fungi in a temperate steppe in Inner Mongolia. Soil Biol. Biochem. 2014, 69, 371-381. [CrossRef]

58. Vicente-Sánchez, J.; Nicolás, E.; Pedrero, F.; Alarcón, J.J.; Maestre-Valero, J.F.; Fernández, F. Arbuscular mycorrhizal symbiosis alleviates detrimental effects of saline reclaimed water in lettuce plants. Mycorrhiza 2014, 24, 339-348. [CrossRef] [PubMed] 
59. Gómez-Bellot, M.J.; Ortuño, M.F.; Nortes, P.A.; Vicente-Sánchez, J.; Bañón, S.; Sánchez-Blanco, M.J. Mycorrhizal euonymus plants and reclaimed water: Biomass, water status and nutritional responses. Sci. Hort. 2015, 186, 61-69. [CrossRef]

60. Tuteja, N. Mechanisms of high salinity tolerance in plants. Methods Enzymol. 2007, 428, 419-438. [PubMed]

61. Evelin, H.; Devi, T.S.; Gupta, S.; Kapoor, R. Mitigation of Salinity Stress in Plants by Arbuscular Mycorrhizal Symbiosis: Current Understanding and New Challenges. Front. Plant Sci. 2019, 14, 470. [CrossRef]

62. Asins, M.J.; Villalta, I.; Aly, M.M.; Olías, R.; Álvarez de Morales, P.; Huertas, R.; Li, J.; Jaime-Pérez, N.; Haro, R.; Raga, V.; et al. Two closely linked tomato HKT coding genes are positional candidates for the major tomato QTL involved in $\mathrm{Na}+/ \mathrm{K}+$ homeostasis. Plant Cell Environ. 2013, 36, 1171-1191. [CrossRef]

63. Porcel, R.; Aroca, R.; Azcon, R.; Ruiz-Lozano, J.M. Regulation of cation transporter genes by the arbuscular mycorrhizal symbiosis in rice plants subjected to salinity suggests improved salt tolerance due to reduced $\mathrm{Na}(+)$ root-to-shoot distribution. Mycorrhiza 2016, 26, 673-684. [CrossRef]

64. Chen, J.; Zhang, H.; Zhang, X.; Tang, M. Arbuscular Mycorrhizal Symbiosis Alleviates Salt Stress in Black Locust through Improved Photosynthesis, Water Status, and K+/Na+ Homeostasis. Front. Plant Sci. 2017, 8 , 1739. [CrossRef]

65. Vosátka, M.; Látr, A.; Gianinazzi, S.; Albrechtová, J. Development of arbuscular mycorrhizal biotechnology and industry: current achievements and bottlenecks. Symbiosis 2012, 58, 29-37.

66. Rillig, M.C.; Sosa-Hernández, M.A.; Roy, J.; Aguilar-Trigueros, C.A.; Vályi, K.; Lehmann, A. Towards an integrated mycorrhizal technology: harnessing mycorrhiza for sustainable intensification in agriculture. Front. Plant Sci. 2016, 7, 1625. [CrossRef]

67. Torres, N.; Antolín, M.C.; Goicoechea, N. Arbuscular Mycorrhizal Symbiosis as a Promising Resource for Improving Berry Quality in Grapevines Under Changing Environments. Front. Plant Sci. 2018, 9, 897. [CrossRef]

68. Bowles, T.M.; Barrios-Masias, F.H.; Carlisle, E.A.; Cavagnaro, T.R.; Jackson, L.E. Effects of arbuscular mycorrhizae on tomato yield, nutrient uptake, water relations, and soil carbon dynamics under deficit irrigation in field conditions. Sci. Total Environ. 2016, 566, 1223-1234. [CrossRef]

69. Satir, N.Y.; Ortas, I.; Satir, O. The influence of mycorrhizal species on sour orange (Citrus aurantium L.) growth under saline soil conditions. Pak. J. Agr. Sci. 2016, 53, 399-406.

70. Torres, N.; Goicoechea, N.; Antolín, M.C. Influence of irrigation strategy and mycorrhizal inoculation on fruit quality in different clones of Tempranillo grown under elevated temperatures. Agric. Water Manag. 2018, 202, 285-298. [CrossRef]

71. Chandrasekaran, M.; Chanratana, M.; Kim, K.; Seshadri, S.; Sa, T. Impact of Arbuscular Mycorrhizal Fungi on Photosynthesis, Water Status, and Gas Exchange of Plants Under Salt Stress-A Meta-Analysis. Front. Plant Sci. 2019, 10, 457. [CrossRef]

72. Smith, S.E.; Smith, F.A. Roles of arbuscular mycorrhizas in plant nutrition and growth: new paradigms from cellular to ecosystem scales. Annu. Rev. Plant Biol. 2011, 62, 227-250. [CrossRef]

73. Ruiz-Lozano, J.M.; Azcón, R. Symbiotic efficiency and infectivity of an autochthonous arbuscular mycorrhizal Glomus sp. from saline soils and Glomus deserticola under salinity. Mycorrhiza 2000, 10, 137-143. [CrossRef]

74. Estrada, B.; Aroca, R.; Barea, J.M.; Ruiz-Lozano, J.M. Native arbuscular mycorrhizal fungi isolated from a saline habitat improved maize antioxidant systems and plant tolerance to salinity. Plant Sci. 2013, 201, 42-51. [CrossRef]

75. Gosling, P.; Jones, J.; Bending, G.D. Evidence for functional redundancy in arbuscular mycorrhizal fungi and implications for agroecosystem management. Mycorrhiza 2016, 26, 77-83. [CrossRef]

76. Kloepper, J.W.; Lifshitz, R.; Zablotowicz, R.M. Free-living bacterial inocula for enhancing crop productity. Trends Bio-Technol. 1989, 7, 39-43. [CrossRef]

77. Antoun, H.; Kloepper, J.W. Plant growth promoting rhizo-bacteria. In Encyclopedia of Genetics; Brenner, S., Miller, J.H.., Eds.; Academic: New York, NY, USA, 2001; pp. 1477-1480.

78. Podile, AR.; Kishore, G.K. Plant growth-promoting rhizobacteria. In Plant-Associated Bacteria; Gnanamanickam, S.S., Ed.; Springer: Dordrecht, The Netherlands, 2006; pp. 195-230.

79. Gray, E.J.; Smith, D.L. Intracellular and extracellular PGPR: Commonalities and distinctions in the plant-bacterium signaling processes. Soil Biol. Biochem. 2005, 37, 395-412. [CrossRef]

80. Lugtenberg, B.; Kamilova, F. Plant-growth-promoting rhizobacteria. Annu. Rev. Microbiol. 2009, 63, 541-555. [CrossRef] [PubMed] 
81. Beneduzi, A.; Ambrosini, A.; Passaglia, L.M. Plant growth-promoting rhizobacteria (PGPR): Their potential as antagonists and biocontrol agents. Genet Mol Biol. 2012, 35, 1044-1051. [CrossRef] [PubMed]

82. Glick, B.R. The enhancement of plant growth by free-living bacteria. Can. J. Microbiol. 1995, 41, $109-117$.

83. El-Sayed, W.S.; Akhkha, A.; El-Naggar, M.Y.; Elbadry, M. In vitro antagonistic activity, plant growth promoting traits and phylogenetic affiliation of rhizobacteria associated with wild plants grown in arid soil. Front Microbiol. 2014, 5, 651. [CrossRef] [PubMed]

84. Olanrewaju, O.S.; Glick, B.R.; Babalola, O.O. Mechanisms of action of plant growth promoting bacteria. World J. Microbiol. Biotechnol. 2017, 33, 197. [CrossRef] [PubMed]

85. Mhlongo, M.I.; Piater, L.A.; Madala, N.E.; Labuschagne, N.; Dubery, I.A. The chemistry of plant-microbe interactions in the rhizosphere and the potential for metabolomics to reveal signaling related to defense priming and induced systemic resistance. Front. Plant Sci. 2018, 9, 112. [CrossRef]

86. Haas, D.; Keel, C. Regulation of antibiotic production in root-colonizing Pseudomonas spp. and relevance for biological control of plant disease. Annu. Rev. Phytopathol. 2003, 41, 117-153. [CrossRef]

87. Couillerot, O.; Prigent-Combaret, C.; Caballero-Mellado, J.; Moënne-Loccoz, Y. Pseudomonas fluorescens and closely-related fluorescent pseudomonads as biocontrol agents of soil-borne phytopathogens. Lett. Appl. Microbiol. 2009, 48, 505-512. [CrossRef]

88. Ramette, A.; Moënne-Loccoz, Y.; Défago, G. Genetic diversity and biocontrol potential of fluorescent pseudomonads producing phloroglucinols and hydrogen cyanide from Swiss soils naturally suppressive or conducive to Thielaviopsis basicola-mediated black root rot of tobacco. FEMS Microbiol. Ecol. 2006, 55, 369-381. [CrossRef]

89. Glick, B.R. Beneficial Plant-Bacterial Interactions; Springer International Publishing: Cham, Switzerland, 2015.

90. Husson, E.; Hadad, C.; Huet, G.; Laclef, S.; Lesur, D.; Lambertyn, V.; Jamali, A.; Gottis, S.; Sarazin, C.; Nguyen Van Nhiem, A. Effect of room temperature ionic liquids on selective biocatalytic hydrolysis of chitin via sequential or simultaneous strategies. Green Chem. 2017, 19, 4122-4131. [CrossRef]

91. Sayyed, R.Z.; Chincholkar, S.B.; Reddy, M.S.; Gangurde, N.S.; Patel, P.R. Siderophore Producing PGPR for Crop Nutrition and Phytopathogen Suppression. In Bacteria in Agrobiology: Disease Management; Maheshwari, D., Ed.; Springer: Berlin/Heidelberg, Germany, 2013; pp. 449-471.

92. Ferreira, C.M.H.; Vilas-Boas, Â.; Sousa, C.A.; Soares, H.M.V.M.; Soares, E.V. Comparison of five bacterial strains producing siderophores with ability to chelate iron under alkaline conditions. AMB Express 2019, 9, 78. [CrossRef] [PubMed]

93. Siddiqui, I.A.; Shaukat, S.S.; Sheikh, I.H.; Khan, A. Role of cyanide production by Pseudomonas fluorescens $\mathrm{CHA}$ in the suppression of root-knot nematode, Meloidogyne javanica in tomato. World J. Microbiol. Biotechnol. 2006, 22, 641-650. [CrossRef]

94. Das, K.; Prasanna, R.; Saxena, A.K. Rhizobia: A potential biocontrol agent for soilborne fungal pathogens. Folia Microbiol. (Praha) 2017, 62, 425-435. [CrossRef] [PubMed]

95. Hernández-Calderón, E.; Aviles-Garcia, M.E.; Castulo-Rubio, D.Y.; Macías-Rodríguez, L.; Ramírez, V.M.; Santoyo, G.; Lopez-Bucio, J.; Valencia-Cantero, E. Volatile compounds from beneficial or pathogenic bacteria differentially regulate root exudation, transcription of iron transporters, and defense signaling pathways in Sorghum bicolor. Plant Mol. Biol. 2018, 96, 291-304. [CrossRef] [PubMed]

96. Sharifi, R.; Ryu, C.M. Revisiting bacterial volatile-mediated plant growth promotion: lessons from the past and objectives for the future. Ann. Bot. 2018, 122, 349-358. [CrossRef]

97. Oke, V.; Long, S.R. Bacterial genes induced within the nodule during the Rhizobium-legume symbiosis. Mol. Microbiol. 2002, 32, 837-849. [CrossRef]

98. Beattie, G.A. Plant-associated bacteria: Survey, molecular phylogeny, genomics and recent advances. In Plant-Associated Bacteria; Gnanamanickam, S.S., Ed.; Springer: Dordrecht, The Netherlands, 2006; pp. 1-56.

99. Pii, Y.; Mimmo, T.; Tomasi, N.; Terzano, R.; Cesco, S.; Crecchio, C. Microbial interactions in the rhizosphere: beneficial influences of plant growth-promoting rhizobacteria on nutrient acquisition process: A review. Biol. Fert. Soils 2015, 51, 403-415. [CrossRef]

100. Glick, B.R.; Bashan, Y. Genetic manipulation of plant growth-promoting bacteria to enhance biocontrol of phytopathogens. Biotechnol. Adv. 1997, 15, 353-378. [CrossRef]

101. Kohler, J.; Caravaca, F.; Carrasco, L.; Roldan, A. Contribution of Pseudomonas mendocina and Glomus intraradices to aggregates stabilization and promotion of biological properties in rhizosphere soil of lettuce plants under field conditions. Soil Use Manag. 2006, 22, 298-304. [CrossRef] 
102. Glick, B.R.; Cheng, Z.; Czarny, J.; Duan, J. Promotion of plant growth by ACC deaminase-producing soil bacteria. Eur. J. Plant Pathol. 2007, 119, 329-339. [CrossRef]

103. Mohamed, H.I.; Gomaa, E.Z. Effect of plant growth promoting Bacillus subtilis and Pseudomonas fluorescens on growth and pigment composition of radish plants (Raphanus sativus) under $\mathrm{NaCl}$ stress. Photosynthetica 2012, 50, 263-272. [CrossRef]

104. Belimov, A.A.; Dodd, I.C.; Hontzeas, N.; Theobald, J.C.; Safronova, V.I.; Davies, W.J. Rhizosphere bacteria containing 1-aminocyclopropane-1-carboxylate deaminase increase yield of plants grown in drying soil via both local and systemic hormone signalling. New Phytol. 2009, 181, 413-423. [CrossRef] [PubMed]

105. Bashan, Y.; de-Bashan, L.E. Inoculant preparation and formulations for Azospirillum spp. In Handbook for Azospirillum: Technical Issues and Protocols; Cassán, F.D., Okon, Y., Creus, C.M., Eds.; Springer: Cham, Switzerland, 2015; pp. 469-485.

106. Schütz, L.; Gattinger, A.; Meier, M.; Müller, A.; Boller, T.; Mäder, P.; Mathimaran, N. Improving Crop Yield and Nutrient Use Efficiency via Biofertilization-A Global Meta-analysis. Front. Plant Sci. 2017, 8, 2204. [CrossRef] [PubMed]

107. Backer, R.; Rokem, J.S.; Ilangumaran, G.; Lamont, J.; Praslickova, D.; Ricci, E.; Subramanian, S.; Smith, D.L. Plant Growth-Promoting Rhizobacteria: Context, Mechanisms of Action, and Roadmap to Commercialization of Biostimulants for Sustainable Agriculture. Front. Plant Sci. 2018, 9, 1473. [CrossRef] [PubMed]

108. Ruzzi, M.; Aroca, R. Plant growth-promoting rhizobacteria act as biostimulants in horticulture. Sci. Hortic. 2015, 196, 124-134. [CrossRef]

109. Gouda, S.; Kerry, R.G.; Das, G.; Paramithiotis, S.; Shin, H.S.; Patram, J.K. Revitalization of plant growth promoting rhizobacteria for sustainable development in agriculture. Microbiol. Res. 2018, 206, 131-140. [CrossRef]

110. Kang, S.M.; Radhakrishnan, R.; Khan, A.L.; Kim, M.J.; Park, J.M.; Kim, B.; Shin, D.H.; Lee, I.J. Gibberellin secreting rhizobacterium, Pseudomonas putida H-2-3 modulates the hormonal and stress physiology of soybean to improve the plant growth under saline and drought conditions. Plant Physiol. Biochem. 2014, 84, 115-124. [CrossRef]

111. Compant, S.; Saikkonen, K.; Mitter, B.; Campisano, A.; Mercado-Blanco, J. Editorial special issue: soil, plants and endophytes. Plant Soil 2016, 405, 1-11. [CrossRef]

112. Ilangumaran, G.; Smith, D.L. Plant growth promoting rhizobacteria in amelioration of salinity stress: A systems biology perspective. Front. Plant Sci. 2017, 8, 1768. [CrossRef]

113. Nelson, L.M. Plant Growth Promoting Rhizobacteria (PGPR): Prospects for New Inoculants. Crop Manag. 2004, 3. [CrossRef]

114. Bhattacharyya, P.N.; Jha, D.K. Plant growth-promoting rhizobacteria (PGPR): emergence in agriculture. World J. Microbiol. Biotechnol. 2012, 28, 1327-1350. [CrossRef] [PubMed]

115. Van Loon, L.C. Plant responses to plant growth-promoting rhizobacteria. Eur. J. Plant Pathol. 2007, 119, 243-254. [CrossRef]

116. Pan, J.; Peng, F.; Xue, X.; You, Q.; Zhang, W.; Wang, T.; Huang, C. The Growth Promotion of Two Salt-Tolerant Plant Groups with PGPR Inoculation: A Meta-Analysis. Sustainability 2019, 11, 378. [CrossRef]

117. Mayak, S.; Tirosh, T.; Glick, B.R. Plant growth-promoting bacteria confer resistance in tomato plants to salt stress. Plant Physiol. Biochem. 2004, 42, 565-572. [CrossRef]

118. Tank, N.; Saraf, M. Salinity-resistant plant growth promoting rhizobacteria ameliorates sodium chloride stress on tomato plants. J. Plant Interact. 2010, 5, 51-58. [CrossRef]

119. Chang, P.; Gerhardt, K.E.; Huang, X.D.; Yu, X.M.; Glick, B.R.; Gerwing, P.D.; Greenberg, B.M. Growth-Promoting Bacteria Facilitate the Growth of Barley and Oats in Salt-Impacted Soil: Implications for Phytoremediation of Saline Soils. Int. J. Phytoremediat. 2014, 16, 1133-1147. [CrossRef]

120. Fan, P.; Chen, D.; He, Y.; Zhou, Q.; Tian, Y.; Gao, L. Alleviating salt stress in tomato seedlings using Arthrobacter and Bacillus megaterium isolated from the rhizosphere of wild plants grown on saline-alkaline lands. Int. J. Phytoremediat. 2016, 18, 1113-1121. [CrossRef]

121. Yang, J.; Kloepper, J.W.; Ryu, C.M. Rhizosphere bacteria help plants tolerate abiotic stress. Trends Plant Sci. 2010, 14, 1-4. [CrossRef]

122. Reed, M.L.E.; Glick, B.R. Growth of canola (Brassica napus) in the presence of plant growth-promoting bacteria and either copper or polycyclic aromatic hydrocarbons. Can. J. Microbiol. 2005, 51, 1061-1069. [CrossRef] 
123. Barassi, C.A.; Ayrault, G.; Creus, C.M.; Sueldo, R.J.; Sobrero, M.T. Seed inoculation with Azospirillum mitigates $\mathrm{NaCl}$ effects on lettuce. Sci. Hortic. 2006, 109, 8-14. [CrossRef]

124. Chakraborty, U.; Roy, S.; Chakraborty, A.P.; Dey, P.; Chakraborty, B. Plant Growth Promotion and Amelioration of Salinity Stress in Crop Plants by a Salt-Tolerant Bacterium. Recent Res. Sci. Technol. 2011, 3, 61-70.

125. Ashraf, M.; Berge, S.H.; Mahmood, O.T. Inoculating wheat seedlings with exopolysaccharide producing bacteria restricts sodium uptake and stimulates plant growth under salt stress. Biol. Fert. Soils 2004, 40, 157-162. [CrossRef]

126. Gururani, M.A.; Upadhyaya, C.P.; Baskar, V.; Venkatesh, J.; Nookaraju, A.; Park, S.W. Plant Growth-Promoting Rhizobacteria Enhance Abiotic Stress Tolerance in Solanum tuberosum Through Inducing Changes in the Expression of ROS-Scavenging Enzymes and Improved Photosynthetic Performance. J. Plant Growth Regul. 2012, 32, 245-258. [CrossRef]

127. Paul, D.; Lade, H. Plant-growth-promoting rhizobacteria to improve crop growth in saline soils: A review. Agron. Sustain. Dev. 2014, 34, 737-752. [CrossRef]

128. Upadhyay, S.K.; Singh, D.P. Effect of salt-tolerant plant growth-promoting rhizobacteria on wheat plants and soil health in a saline environment. Plant Biol. 2015, 17, 288-293. [CrossRef] [PubMed]

129. Hamdia, A.B.E.; Shaddad, M.A.K.; Doaa, M.M. Mechanisms of salt tolerance and interactive effects of Azospirillum brasilense inoculation on maize cultivars grown under salt stress conditions. Plant Growth Regul. 2004, 44, 165-174. [CrossRef]

130. Han, H.S.; Lee, K.D. Physiological Responses of Soybean - Inoculation of Bradyrhizobium japonicum with PGPR in Saline Soil Conditions. Res. J. Agric. E Biol. Sci. 2005, 1, 216-221.

131. Kohler, J.; Hernández, J.A.; Caravaca, F.; Roldán, A. Induction of antioxidant enzymes is involved in the greater effectiveness of a PGPR versus AM fungi with respect to increasing the tolerance of lettuce to severe salt stress. Environ. Exp. Bot. 2009, 65, 245-252. [CrossRef]

132. Wang, W.; Wu, Z.; He, Y.; Huang, Y.; Li, X.; Ye, B.C. Plant growth promotion and alleviation of salinity stress in Capsicum annuum L. by Bacillus isolated from saline soil in Xinjiang. Ecotox. Environ. Safe. 2018, 164, 520-529. [CrossRef]

133. Singh, R.P.; Jha, P.N. The Multifarious PGPR Serratia marcescens CDP-13 Augments Induced Systemic Resistance and Enhanced Salinity Tolerance of Wheat (Triticum aestivum L.). PLoS ONE 2016, 11, e0155026. [CrossRef]

134. Dardanelli, M.S.; Fernández de Córdoba, F.J.; Espuny, M.R.; Rodríguez-Carvajal, M.A.; Soría-Díaz, M.E.; Gil-Serrano, A.M.; Okon, Y.; Megías, M. Effect of Azospirillum brasilense coinoculated with Rhizobium on Phaseolus vulgaris flavonoids and Nod factor production under salt stress. Soil Biol. Biochem. 2008, 40, 2713-2721. [CrossRef]

135. Cheng, Z.; Park, E.; Glick, B.R. 1-Aminocyclopropane-1-carboxylate deaminase from Pseudomonas putida UW4 facilitates the growth of canola in the presence of salt. Can. J. Microbiol. 2007, 53, 912-918. [CrossRef] [PubMed]

136. Nadeem, S.J.; Zahir, Z.A.; Naveed, M.; Arshad, M. Preliminary investigations on inducing salt tolerance in maize through inoculation with rhizobacteria containing ACC deaminase activity. Can. J. Microbiol. 2007, 53, 1141-1149. [CrossRef] [PubMed]

137. Zaidi, A.; Khan, S.; Ahemad, M.; Oves, M. Plant growthpromotion by phosphate solubilizing bacteria. Acta Microbiol. Immunol. Hung. 2009, 56, 263-284. [CrossRef] [PubMed]

138. Shi, H.; Ishitani, M.; Kim, C.; Zhu, J.K. The Arabidopsis thaliana salt tolerance gene SOS1 encodes a putative $\mathrm{Na}+\mathrm{H}+$ antiporter. Proc. Natl. Acad. Sci. USA 2000, 97, 6896-6901. [CrossRef]

139. Bharti, N.; Pandey, S.S.; Barnawal, D.; Patel, V.K.; Kalra, A. Plant growth promoting rhizobacteria Dietzia natronolimnaea modulates the expression of stress responsive genes providing protection of wheat from salinity stress. Sci Rep. 2016, 6, 34768. [CrossRef]

140. Chen, M.; Wei, H.; Cao, J.; Liu, R.; Wang, Y.; Zheng, C. Expression of Bacillus subtilis proBA genes and reduction of feedback inhibition of proline synthesis increases proline production and confers osmotolerance in transgenic Arabidopsis. J. Biochem. Mol. Biol. 2007, 40, 396-403. [CrossRef]

141. Pérez-Montaño, F.; Alías-Villegas, C.; Bellogín, R.A.; del Cerro, P.; Espuny, M.R.; Jiménez-Guerrero, I.; López-Baena, F.J.; Ollero, F.J.; Cubo, T. Plant growth promotion in cereal and leguminous agricultural important plants: From microorganism capacities to crop production. Microbiol. Res. 2014, 169, 325-336. [CrossRef] 
142. Bishnoi, U. PGPR Interaction: An Ecofriendly Approach Promoting the Sustainable Agriculture System. In Advances in Botanical Research; Bais, H., Sherrier, J., Eds.; Academic Research: New York, NY, USA, 2015; Volume 75, pp. 81-113.

143. Chen, T.H.H.; Murata, N. Enhancement of tolerance of abiotic stress by metabolic engineering of betaines and other compatible solutes. Curr. Opin. Plant Biol. 2002, 5, 250-257. [CrossRef]

144. Nounjana, N.; Nghiab, P.T.; Theerakulpisut, P. Exogenous proline and trehalose promote recovery of rice seedlings from salt-stress and differentially modulate antioxidant enzymes and expression of related genes. J. Plant Physiol. 2012, 169, 596-604. [CrossRef]

145. Singh, M.; Kumar, J.; Singh, V.P.; Prasad, S.M. Proline and Salinity Tolerance in Plants. Biochem. Pharmacol. 2014, 3, 6. [CrossRef]

146. Wutipraditkul, N.; Wongwean, P.; Buaboocha, T. Alleviation of salt-induced oxidative stress in rice seedlings by proline and/or glycinebetaine. Biol. Plant. 2015, 59, 547-553. [CrossRef]

147. Yang, S.L.; Lan, S.S.; Gong, M. Hydrogen peroxide-induced proline andmetabolic pathway of its accumulation in maize seedlings. J. Plant Physiol. 2009, 166, 1694-1699. [CrossRef] [PubMed]

148. Bulgari, R.; Franzoni, G.; Ferrante, A. Biostimulants Application in Horticultural Crops under Abiotic Stress Conditions. Agronomy 2019, 9, 306. [CrossRef]

149. Ahmed, C.B.; Rouina, B.B.; Sensoy, S.; Boukhriss, M.; Abdullah, F.B. Exogenous Proline Effects on Photosynthetic Performance and Antioxidant Defense System of Young Olive Tree. J. Agric. Food Chem. 2010, 58, 4216-4222. [CrossRef] [PubMed]

150. Nawaz, K.; Talat, A.; Iqra, K.H.; Majeed, A. Induction of salt tolerance in two cultivars of sorghum (Sorghum bicolor L.) by exogenous application of proline at seedling stage. World Appl. Sci. J. 2010, 10, 93-99.

151. Talat, A.; Nawaz, K.; Hussian, K.; Bhatti, K.H.; Siddigi, E.H.; Khalid, A.; Anwer, S.; Sharif, M.U. Foliar Application of Proline for Salt Tolerance of Two Wheat (Triticum aestivum L.) Cultivars. World Appl. Sci. J. 2013, 22, 547-554.

152. Abdel Latef, A.A.H.; Srivastava, A.K.; Saber, H.; Alwaleed, E.A.; Tran, L.S.P. Sargassum muticum and Jania rubens regulate amino acid metabolism to improve growth and alleviate salinity in chickpea. Sci. Rep. 2017, 7,1-12. [CrossRef]

153. Abdelhamid, M.T.; Rady, M.M.; Osman, A.Sh.; Abdalla, M.A. Exogenous application of proline alleviates salt-induced oxidative stress in Phaseolus vulgaris L. plants. J. Hortic. Sci. Biotech. 2013, 88, 439-446. [CrossRef]

154. Heuer, B. Influence of exogenous application of proline and glycinebetaine on growth of salt-stressed tomato plants. Plant Sci. 2003, 165, 693-699. [CrossRef]

155. Roy, D.; Basu, N.; Bhunia, A.; Banerjee, S. Counteraction of exogenous L-proline with $\mathrm{NaCl}$ in salt-sensitive cultivar of rice. Biol. Plant. 1993, 35, 69-72. [CrossRef]

156. Chen, S.L.; Kao, C.H. Cadmium induced changes in proline level and peroxidase activity in roots of rice seedlings. Plant Growth Regul. 1995, 17, 67-71.

157. Ashraf, M.; Foolad, M.R. Roles of glycine betaine and proline in improving plant abiotic stress resistance. Environ. Exp. Bot. 2007, 59, 206-216. [CrossRef]

158. Giri, J. Glycinebetaine and abiotic stress tolerance in plants. Plant Signal. Behav. 2011, 6, 1746-1751. [CrossRef]

159. Annunziata, M.G.; Ciarmiello, L.F.; Woodrow, P.; Dell'Aversana, E.; Carillo, P. Spatial and Temporal Profile of Glycine Betaine Accumulation in Plants Under Abiotic Stresses. Front. Plant Sci. 2019, 10, 230. [CrossRef]

160. Kumar, S.; Dhingra, A.; Daniell, H. Plastid-expressed betaine aldehyde dehydrogenase gene in carrot cultured cells, roots, and leaves confers enhanced salt tolerance. Plant Physiol. 2004, 136, 2843-2854. [CrossRef]

161. Kishitani, S.; Takanami, T.; Suzuki, M.; Oikawa, M.; Yokoi, S.; Ishitani, M.; Alvarez-Nakase, A.M.; Takabe, T.; Takabe, T. Compatibility of glycinebetaine in rice plants: evaluation using transgenic rice plants with a gene for peroxisomal betaine aldehyde dehydrogenase from barley. Plant Cell Environ. 2000, 23, 107-114. [CrossRef]

162. Shirasawa, K.; Takabe, T.; Takabe, T.; Kishitani, S. Accumulation of glycinebetaine in rice plants that overexpress choline monooxygenase from spinach and evaluation of their tolerance to abiotic stress. Ann. Bot. 2006, 98, 565-571. [CrossRef]

163. Demiral, T.; Türkan, I. Does exogenous glycinebetaine affect antioxidative system of rice seedlings under $\mathrm{NaCl}$ treatment? J. Plant Physiol. 2004, 161, 1089-1100. [CrossRef] 
164. Ibrahim, M.; Anjum, A.; Khaliq, N.; Iqbal, M.; Athar, H.U.R. Four foliar applications of glycine betaine did not alleviate adverse effects of salt stress on growth of sunflower. Pak. J. Biol. Sci. 2006, 38, 1561-1570.

165. Nawaz, K.; Ashraf, M. Improvement in salt tolerance of maize by exogenous application of glycinbetain: growth and water relations. Pak. J. Biol. Sci. 2007, 39, 1647-1653.

166. Athar, H.R.; Ashraf, M.; Wahid, A.; Jamil, A. Inducing salt tolerance in Canola (Brassica napus L.) by exogenous application of Glycine beanie and proline: response at the initial growth stages. Pak. J. Biol. Sci. 2009, 41, 1311-1319.

167. Abbas, W.; Ashraf, M.; Akram, N.A. Alleviation of salt-induced adverse effects in eggplant (Solanum melongena L.) by glycinebetaine and sugarbeet extracts. Sci. Hortic. 2010, 125, 188-195. [CrossRef]

168. Korkmaz, A.; Sirikci, R. Improving salinity tolerance of germinating seeds by exogenous application of glycine betaine in pepper. Seed Sci. Technol. 2011, 39, 377-388. [CrossRef]

169. Hu, L.; Hu, T.; Zhang, X.; Pang, H.; Fu, J. Exogenous glycine betaine ameliorates adverse effects of salt stress on perennial ryegrass. J. Am. Soc. Hortic. Sci. 2012, 137, 38-46. [CrossRef]

170. Shams, M.; Yildirim, E.; Ekinci, M.; Turan, M.; Dursun, A.; Parlakova, F.; Kul, R. Exogenously applied glycine betaine regulates some chemical characteristics and antioxidative defence systems in lettuce under salt stress. Hortic. Environ. Biote. 2016, 57, 225-231. [CrossRef]

171. Alasvandyari, F.; Mahdavi, B.; Hosseini, S.M. Glycine betaine affects the antioxidant system and ion accumulation and reduces salinity-induced damage in safflower seedlings. Arch. Agron. Soil Sci. 2017, 69, 139-147. [CrossRef]

172. Kumar, P.; Sharma, V.; Atmaram, C.K.; Singh, B. Regulated partitioning of fixed carbon (14C), sodium (Na+), potassium $(\mathrm{K}+)$ and glycine betaine determined salinity stress tolerance of gamma irradiated pigeon pea [Cajanus cajan (L.) Millsp]. Environ. Sci. Pollut. Res. Int. 2017, 24, 7285-7297. [CrossRef]

173. Sabagh, A.E.; Sorour, S.; Ragab, A.; Saneoka, H.; Islam, M.S. The effect of exogenous application of proline and glycine betaine on the nodule activity of soybean under saline condition. J. Agr. Biotechnol. 2017, 2, 01-05.

174. Tian, F.; Wang, W.; Liang, C.; Wang, X.; Wang, G.; Wang, W. Overaccumulation of glycine betaine makes the function of the thylakoid membrane better in wheat under salt stress. Crop J. 2017, 7, 73-82. [CrossRef]

175. Wei, D.; Zhang, W.; Wang, C.; Meng, Q.; Li, G.; Chen, T.H.H.; Yang, X. Genetic engineering of the biosynthesis of glycinebetaine leads to alleviate salt-induced potassium efflux and enhances salt tolerance in tomato plants. Plant Sci. 2017, 257, 74-83. [CrossRef]

176. Liang, C.; Zhang, X.Y.; Luo, Y.; Wang, G.P.; Zou, Q.; Wang, W. Overaccumulation of glycinebetaine alleviates the negative effects of salt stress in wheat. Russ. J. Plant. Physiol. 2009, 56, 410-417. [CrossRef]

177. Kusano, T.; Berberich, T.; Tateda, C.; Takahashi, Y. Polyamines: essential factors for growth and survival. Planta 2008, 228, 367-381. [CrossRef] [PubMed]

178. Hussain, S.S.; Ali, M.; Ahmad, M.; Siddique, K.H.M. Polyamines: Natural and engineered abiotic and biotic stress tolerance in plants. Biotechnol. Adv. 2011, 29, 300-311. [CrossRef] [PubMed]

179. Tiburcio, A.F.; Altabella, T.; Bitrián, M.; Alcázar, R. The roles of polyamines during the lifespan of plants: from development to stress. Planta 2014, 240, 1-18. [CrossRef] [PubMed]

180. Shevyakova, N.I.; Shorina, M.V.; Rakitin, V.Y.; Kuznetsov, V. Stress-dependent accumulation of spermidine and spermine in the halophyte Mesembryanthemum crystallinum under salinity conditions. Russ. J. Plant Physiol. 2006, 53, 739-745. [CrossRef]

181. Kuznetsov, V.V.; Shevyakova, N.N. Polyamines and stress tolerance of plants. Plant Stress. 2007, 1, 50-71.

182. Zhao, F.G.; Qin, P. Protective effect of exogenous polyamines on root tonoplast function against salt stress in barley seedlings. Plant Growth Regul. 2004, 42, 97-103. [CrossRef]

183. Roy, P.; Niyogi, K.; Sengupta, D.N.; Ghosh, B. Spermidine treatment to rice seedlings recovers salinity stress-induced damage of plasma membrane and PM-bound Hp-ATPase in salt-tolerant and salt-sensitive rice cultivars. Plant Sci. 2005, 168, 583-591. [CrossRef]

184. Ikbal, F.E.; Hernández, J.A.; Barba-Espín, G.; Koussa, T.; Aziz, A.; Faize, M.; Diaz-Vivancos, P. Enhanced salt-induced antioxidative responses involve a contribution of polyamine biosynthesis in grapevine plants. J. Plant Physiol. 2014, 171, 779-788. [CrossRef]

185. Parvin, S.; Lee, O.R.; Sathiyaraj, G.; Khorolragchaa, A.; Kim, Y.J.; Yang, D.C. Spermidine alleviates the growth of saline-stressed ginseng seedlings through antioxidative defense system. Gene 2014, 537, 70-78. [CrossRef] [PubMed] 
186. Malliarakis, D.; Tsiavos, T.; Ionnadis, N.E.; Kotzabasis, K. Spermine and lutein quench chlorophyll fluorescence in isolated PSII antenna complexes. J. Plant Physiol. 2015, 183, 108-113. [CrossRef] [PubMed]

187. Nahar, K.; Hasanuzzaman, M.; Rahman, A.; Alam, M.M.; Al Mahmud, J.; Suzuki, T.; Fujita, M. Polyamines confer salt tolerance in mung bean (Vigna radiata L.) by reducing sodium uptake, improving nutrient homeostasis, antioxidant defense, and methylglyoxal detoxification systems. Front. Plant Sci. 2016, 7, 1104. [CrossRef] [PubMed]

188. Zhong, M.; Yuan, Y.; Shu, S.; Sun, J.; Guo, S.; Yuan, R.; Tang, Y. Effects of exogenous putrescine on glycolysis and Krebs cycle metabolism in cucumber leaves subjected to salt stress. Plant Growth Regul. 2016, 79, 319-330. [CrossRef]

189. Sudhakar, C.; Veeranagamallaiah, G.; Nareshkumlar, A.; Sundhakarbabu, O.; Sivakumar, M.; Pandurangaiah, M.; Kiranmai, K.; Lokesh, U. Polyamine metabolism influences antioxidant defense mechanisms in foxtail millet (Setaria italica L.) cultivars with different salinity tolerance. Plant Cell Rep. 2015, 34, 141-156. [CrossRef]

190. Pál, M.; Szalai, G.; Janda, T. Speculation: polyamines are important in abiotic stress signaling. Plant Sci. 2015, 237, 16-23. [CrossRef]

191. Llanes, A.; Reginato, M.; Devinar, G.; Luna, V. What is known about phytohormones in halophytes? A review. Biologia 2018, 73, 727-742. [CrossRef]

192. Igarashi, K.; Kashiwagi, K. Modulation of protein synthesis by polyamines. IUBMB Life 2015, 67, 160-169. [CrossRef]

193. Pathak, M.R.; Teixeira da Silva, J.A.; Wani, S.H. Polyamines in response to abiotic stress tolerance through transgenic approaches. GM Crops Food. 2014, 5, 87-96. [CrossRef]

194. Bueno, M.; Cordovilla, M.P. Polyamines in halophytes. Front. Plant Sci. 2019, 10, 439. [CrossRef]

195. Wang, Q.; Bo, Y. Alleviative effects of different kinds of exogenous polyamines on salt injury of Soybean seedlings. J. Henan Agric. Sci. 2014, 43, 48-50.

196. Meng, D.; Hou, L.; Yang, S. Exogenous polyamines alleviating salt stress on peanuts (Arachis hypogaea) grown in pots. Chin. J. Plant Ecol. 2015, 39, 1209-1215.

197. Baniasadi, F.; Saffari, V.R.; Moud, A.A.M. Physiological and growth responses of Calendula officinalis L. plants to the interaction effects of polyamines and salt stress. Sci. Hortic. 2018, 234, 312-317. [CrossRef]

198. Li, B.; Guo, S.; Sun, J.; Li, J. Effects of exogenous spermidine on free polyamine content and polyamine biosynthesis gene expression in cucumber seedlings under salt stress. Plant Sci. J. 2011, 29, 480-485.

199. Takahashi, Y.; Tahara, M.; Yamada, Y.; Mitsudomi, Y.; Kaoruko, K. Characterization of the polyamine biosynthetic pathways and salt stress response in Brachypodium distachyon. J. Plant Growth Regul. 2018, 37, 625-634. [CrossRef]

200. Roy, M.; Wu, R. Overexpression of S-adenosylmethionine decarboxylase gene in rice increases polyamine level and enhances sodium chloride-stress tolerance. Plant Sci. 2002, 163, 987-992. [CrossRef]

201. Hardeland, R. Melatonin in Plants - Diversity of Levels and Multiplicity of Functions. Front. Plant Sci. 2016, 7, 198. [CrossRef]

202. Lerner, A.B.; Case, J.D.; Takahashi, Y.; Lee, T.H.; Mori, W. Isolation of melatonin, the pineal gland factor that lightens melanocytes. J. Am. Chem. Soc. 1958, 80, 2587. [CrossRef]

203. Wei, W.; Li, Q.T.; Chu, Y.N.; Reiter, R.J.; Yu, X.M.; Zhu, D.H.; Zhang, W.K.; Ma, B.; Lin, Q.; Zhang, J.S.; et al. Melatonin enhances plant growth and abiotic stress tolerance in soybean plants. J. Exp. Bot. 2015, 66, 695-707. [CrossRef]

204. Liang, C.; Zheng, G.; Li, W.; Wang, Y.; Hu, B.; Wang, H.; Wu, H.; Qian, Y.; Zhu, X.G.; Tan, D.X.; et al. Melatonin delays leaf senescence and enhances salt stress tolerance in rice. J. Pineal Res. 2015, 59, 91-101. [CrossRef]

205. Arnao, M.B.; Hernández-Ruiz, J. Melatonin: plant growth regulator and/or biostimulator during stress? Trends Plant Sci. 2014, 19, 789-797. [CrossRef] [PubMed]

206. Arnao, M.B.; Hernández-Ruiz, J. Functions of melatonin in plants: A review. J. Pineal Res. 2015, 59, $133-150$. [CrossRef] [PubMed]

207. Arnao, M.B.; Hernández-Ruiz, J. The multi-regulatory properties of melatonin in plants. In Neurotransmitters in Plants; Roshchina, V.V., Ramakrishna, A., Eds.; Taylor \& Francis-CRC: New York, NY, USA, 2018; pp. 71-101.

208. Arnao, M.B.; Hernández-Ruiz, J. Melatonin in its relationship to plant hormones. Ann. Bot. 2018, 121, 195-207. [CrossRef] [PubMed] 
209. Wang, Y.; Reiter, R.J.; Chan, Z. Phytomelatonin: A universal abiotic stress regulator. J. Exp. Bot. 2018, 69, 963-974. [CrossRef]

210. Arnao, M.B.; Hernández-Ruiz, J. Melatonin: A new plant hormone and/or a plant master regulator? Trends Plant Sci. 2019, 24, 38-48. [CrossRef]

211. Kostopoulou, Z.; Therios, I.; Roumeliotis, E.; Kanellis, A.K.; Molassiotis, A. Melatonin combined with ascorbic acid provides salt adaptation in Citrus aurantium L. seedlings. Plant Physiol. Biochem. 2015, 86, 155-165. [CrossRef]

212. Zhan, H.; Nie, X.; Zhang, T.; Li, S.; Wang, X.; Du, X.; Tong, W.; Song, W. Melatonin: A Small Molecule but Important for Salt Stress Tolerance in Plants. Int. J. Mol. Sci. 2019, 20, 709. [CrossRef]

213. Back, K.; Tan, D.X.; Reiter, R.J. Melatonin biosynthesis in plants: multiple pathways catalyze tryptophan to melatonin in the cytoplasm or chloroplasts. J. Pineal Res. 2016, 61, 426-437. [CrossRef]

214. Tan, D.X.; Hardeland, R.; Manchester, L.C.; Korkmaz, A.; Ma, S.; Rosales-Corral, S.; Reiter, R.J. Functional roles of melatonin in plants, and perspectives in nutritional and agricultural science. J. Exp. Bot. 2012, 63, 577-597. [CrossRef]

215. Jiang, C.; Cui, Q.; Feng, K.; Xu, D.; Li, C.; Zheng, Q. Melatonin improves antioxidant capacity and ion homeostasis and enhances salt tolerance in maize seedlings. Acta Physiol. Plant. 2016, 38, 82. [CrossRef]

216. Wang, L.Y.; Liu, J.L.; Wang, W.X.; Sun, Y. Exogenous melatonin improves growth and photosynthetic capacity of cucumber under salinity-induced stress. Photosynthetica 2016, 54, 19-27. [CrossRef]

217. Ke, Q.; Ye, J.; Wang, B.; Ren, J.; Yin, L.; Deng, X.; Wang, S. Melatonin Mitigates Salt Stress in Wheat Seedlings by Modulating Polyamine Metabolism. Front. Plant Sci. 2018, 9, 914. [CrossRef] [PubMed]

218. Yu, Y.; Wang, A.; Li, X.; Kou, M.; Wang, W.; Chen, X.; Xu, T.; Zhu, M.; Ma, D.; Li, Z.; et al. Melatonin-Stimulated Triacylglycerol Breakdown and Energy Turnover under Salinity Stress Contributes to the Maintenance of Plasma Membrane H+-ATPase Activity and K+/Na+ Homeostasis in Sweet Potato. Front. Plant Sci. 2018, 9 , 256. [CrossRef] [PubMed]

219. Chen, Y.; Mao, J.; Sun, L.; Huang, B.; Ding, C.; Gu, Y.; Liao, J.; Hu, C.; Zhang, Z.; Yuan, S.; et al. Exogenous melatonin enhances salt stress tolerance in maize seedlings by improving antioxidant and photosynthetic capacity. Physiol. Plant. 2018, 164, 349-363. [CrossRef]

220. Li, C.; Wang, P.; Wei, Z.; Liang, D.; Liu, C.; Yin, L.; Jia, D.; Fu, M.; Ma, F. The mitigation effects of exogenous melatonin on salinity-induced stress in Malus hupehensis. J. Pineal Res. 2012, 53, 298-306. [CrossRef] [PubMed]

221. Sadak, M.S. Mitigation of salinity adverse effects of on wheat by grain priming with melatonin. Int. J. Chemtech Res. 2016, 9, 85-97.

222. Zhou, X.; Zhao, H.; Cao, K.; Hu, L.; Du, T.; Baluška, F.; Zou, Z. Beneficial Roles of Melatonin on Redox Regulation of Photosynthetic Electron Transport and Synthesis of D1 Protein in Tomato Seedlings under Salt Stress. Front. Plant Sci. 2016, 7, 1823. [CrossRef]

223. Zheng, X.D.; Tan, D.X.; Allan, A.C.; Zuo, B.X.; Zhao, Y.; Reiter, R.J.; Wang, L.; Wang, Z.; Guo, Y.; Zhou, J.Z.; et al. Chloroplastic biosynthesis of melatonin and its involvement in protection of plants from salt stress. Sci. Rep. 2017, 7, 41236. [CrossRef]

224. Li, H.; Chang, J.; Chen, H.; Wang, Z.; Gu, X.; Wei, C.; Zhang, Y.; Ma, J.; Yang, J.; Zhang, X. Exogenous Melatonin Confers Salt Stress Tolerance to Watermelon by Improving Photosynthesis and Redox Homeostasis. Front. Plant Sci. 2017, 8, 295. [CrossRef]

225. Zhao, G.; Zhao, Y.; Yu, X.; Kiprotich, F.; Han, H.; Guan, R.; Wang, R.; Shen, W. Nitric oxide is required for melatonin-enhanced tolerance against salinity stress in rapeseed (Brassica napus L.) seedlings. Int. J. Mol. Sci. 2018, 19, 1912. [CrossRef]

226. Zhang, H.J.; Zhang, N.; Yang, R.C.; Wang, L.; Sun, Q.Q.; Li, D.B.; Cao, Y.Y.; Weeda, S.; Zhao, B.; Ren, S.; et al. Melatonin promotes seed germination under high salinity by regulating antioxidant systems, ABA and GA4 interaction in cucumber (Cucumis sativus L.). J. Pineal Res. 2014, 57, 269-279. [CrossRef] [PubMed]

227. Hernández-Ruiz, J.; Arnao, M.B. Relationship of melatonin and salicylic acid in biotic/abiotic plant stress responses. Agronomy 2018, 8, 33. [CrossRef]

228. Li, C.; Liang, D.; Chang, C.; Jia, D.; Ma, F. Melatonin mediates the regulation of ABA metabolism, free-radical scavenging, and stomatal behavior in two Malus species under drought stress. J. Exp. Bot. 2015, 66, 669-680. [CrossRef] [PubMed] 
229. Liu, J.; Zhai, R.; Liu, F.; Zhao, Y.; Wang, H.; Liu, L.; Yang, C.; Wang, Z.; Ma, F.; Xu, L. Melatonin induces parthenocarpy by regulating genes in gibberellin pathways in 'Starkrimson' pear (Pyrus communis L.). Front. Plant Sci. 2018, 9, 946. [CrossRef] [PubMed]

230. Debnath, B.; Islam, W.; Li, M.; Sun, Y.; Lu, X.; Mitra, S.; Hussain, M.; Liu, S.; Qiu, D. Melatonin mediates enhancement of stress tolerance in plants. Int. J. Mol. Sci. 2019, 20, 1040. [CrossRef]

231. Yu, Y.; Lv, Y.; Shi, Y.; Li, T.; Chen, Y.; Zhao, D.; Zhao, Z. The role of phyto-melatonin and related metabolites in response to stress. Molecules 2018, 23, 1887. [CrossRef]

232. Erland, L.A.E.; Murch, S.J.; Reiter, R.J.; Saxena, P.K. A new balancing act: The many roles of melatonin and serotonin in plant growth and development. Plant Sign. Behav. 2015, 10, e1096469. [CrossRef]

233. Erland, L.A.E.; Saxena, P.K. Melatonin in plant morphogenesis. In Vitro Cell. Dev. Biol. Plant 2018, 54, 3-24. [CrossRef]

234. Fazal, H.; Abbasi, B.H.; Ahmad, N.; Ali, M. Exogenous melatonin trigger biomass accumulation and production of stress enzymes during callogenesis in medicinally important Prunella vulgaris L. (Selfheal). Physiol. Mol. Biol. Plants 2018, 24, 1307-1315. [CrossRef]

235. Wei, J.; Li, D.; Zhang, J.; Shan, C.; Rengel, Z.; Song, Z.; Chen, Q. Phytomelatonin receptor PMTR1-mediated signaling regulates stomatal closure in Arabidopsis thaliana. J. Pineal Res. 2018, 65, e12500. [CrossRef]

236. Dat, J.; Vandenabeele, S.; Vranová, E.; Van Montagu, M.; Inzé, D.; Van Breusegem, F. Dual action of the active oxygen species during plant stress responses. Cell. Mol. Life Sci. 2000, 57, 779-795. [CrossRef] [PubMed]

237. Bailly, C.; El-Maarouf-Bouteau, H.; Corbineau, F. From intracellular signaling networks to cell death: the dual role of reactive oxygen species in seed physiology. Compt. Rend Biol. 2008, 331, 806-814. [CrossRef] [PubMed]

238. Hossain, M.A.; Bhattacharjee, S.; Armin, S.M.; Qian, P.; Xin, W.; Li, H.Y.; Burritt, D.J.; Fujita, M.; Tran, L.S.P. Hydrogen peroxide priming modulates abiotic oxidative stress tolerance: insights from ROS detoxification and scavenging. Front. Plant Sci. 2015, 6, 420. [CrossRef]

239. Fedina, I.S.; Nedeva, D.; Çiçek, N. Pre-treatment with $\mathrm{H}_{2} \mathrm{O}_{2}$ induces salt tolerance in barley seedlings. Biol. Plant. 2009, 53, 321-324. [CrossRef]

240. Li, J.T.; Qiu, Z.B.; Zhang, X.W.; Wang, L.S. Exogenous hydrogen peroxide can enhance tolerance of wheat seedlings to salt stress. Acta Physiol. Plant. 2011, 33, 835-842. [CrossRef]

241. Shan, C.; Liu, R. Exogenous hydrogen peroxide up-regulates the contents of ascorbate and glutathione in the leaves of Vigna radiata (Linn.) Wilczek. exposed to salt stress. Braz. J. Bot. 2017, 40, 583-589. [CrossRef]

242. Smirnoff, N. Ascorbate, Tocopherol and Carotenoids: Metabolism, Pathway Engineering and Functions. In Antioxidants and Reactive Oxygen Species in Plants; Smirnoff, N., Ed.; Blackwell Publishing Ltd.: Oxford, UK, 2005; pp. 53-78.

243. Giil, S.S.; Tuteja, N. Reactive oxygen species and antioxidant machinery in abiotic stress tolerance in crop plants. Plant Physiol. Biochem. 2010, 48, 909-930. [CrossRef]

244. Foyer, C.H.; Noctor, G. Ascorbate and Glutathione: The Heart of the Redox Hub. Plant Physiol. 2011, 155, 2-18. [CrossRef]

245. Akram, N.A.; Shafiq, F.; Ashraf, M. Ascorbic Acid-A Potential Oxidant Scavenger and Its Role in Plant Development and Abiotic Stress Tolerance. Front. Plant Sci. 2017, 8, 613. [CrossRef]

246. Chen, Z.; Gallie, D.R. The Ascorbic Acid Redox State Controls Guard Cell Signaling and Stomatal Movement. Plant Cell 2004, 16, 1143-1162. [CrossRef]

247. Davey, M.W.; van Montagu, M.; Inze, D.; Sanmartin, M.; Kanellis, A.; Smirnoff, N.; Benzie, I.F.F.; Strain, J.J.; Favell, D.; Fletcher, J. Plant L-ascorbic acid: chemistry, function, metabolism, bioavailability and effects of processing. J. Sci. Food Agric. 2000, 89, 825-860. [CrossRef]

248. Khan, T.A.; Mazid, M.; Mohammad, F. A review of ascorbic acid potentialities against oxidative stress induced in plants. J. Agrobiol. 2011, 28, 97-111. [CrossRef]

249. Locato, V.; Cimini, S.; De Gara, L. Strategies to increase Vitamin C in plants: from plant defense perspective to food biofortification. Front. Plant Sci. 2013, 4, 152. [CrossRef] [PubMed]

250. Wang, J.; Zhang, Z.; Huang, R. Regulation of ascorbic acid synthesis in plants. Plant Singnal Behav. 2013, 8 , e24536. [CrossRef] [PubMed] 
251. Hasanuzzaman, M.; Hossain, M.A.; Teixera de Silva, J.A.; Fujita, M. Plant response and tolerance to abiotc oxidative stress: Antioxidant defense is a key factor. In Crop Stress and Its Management: Perspectives and Stragegies; Venkateswarlu, B., Shanker, A.K., Shanker, C., Maheswari, M., Eds.; Springer: New York, NY, USA, 2012; pp. 261-315.

252. Racchi, M.L. Antioxidant defenses in plants with attention to Prunus and Citrus spp. Antioxidants 2013, 2, 340-369. [CrossRef]

253. Hossain, M.A.; Munné-Bosch, S.; Burritt, D.J.; Diaz-Vivancos, P.; Fujita, M.; Lorence, A. Ascorbic Acid in Plant Growth, Development and Stress Tolerance; Springer: Cham, Switzerland, 2018; pp. 1-503.

254. Ragab, M.M. Effect of spraying urea, ascorbic acid and NAA on fruiting of Washington Navel orange trees. Master's Thesis, Faculty of Agriculture Minia University, Minya, Egypt, 2002.

255. Yousef, A.R.M.; Ayad, H.S.; Saleh, M.M.S. The beneficial effect of spraying some antioxidant vitamins on fruit quality, oil composition and improving oil characteristics of Picaul olive. World J. Agric. Sci. 2009, 5, 871-880.

256. Mohamed, A.A.; Ali, S.I.; El-Baz, F.K. Antioxidant and Antibacterial Activities of Crude Extracts and Essential Oils of Syzygium cumini Leaves. PLoS ONE 2013, 8, e60269. [CrossRef]

257. Hussein, M.; Alva, A. Effects of Zinc and Ascorbic Acid Application on the Growth and Photosynthetic Pigments of Millet Plants Grown under Different Salinity. Agric. Sci. 2014, 5, 1253-1260. [CrossRef]

258. Athar, H.; Khan, A.; Ashraf, M. Exogenously applied ascorbic acid alleviates salt-induced oxidative stress in wheat. Environ. Exp. Bot. 2008, 63, 224-231. [CrossRef]

259. El-Sayed, O.M.; El-Gammal, O.H.M.; Salama, A.S.M. Effect of ascorbic acid, proline and jasmonic acid foliar spraying on fruit set and yield of Manzanillo olive trees under salt stress. Sci. Hortic. 2014, 176, 32-37. [CrossRef]

260. Al-Hakimi, A.; Hamada, A. Counteraction of Salinity Stress on Wheat Plants by Grain Soaking in Ascorbic Acid, Thiamin or Sodium Salicylate. Biol. Plant. 2001, 44, 253. [CrossRef]

261. Shalata, A.; Neumann, P.M. Exogenous ascorbic acid (vitamin C) increases resistance to salt stress and reduces lipid peroxidation. J. Exp. Bot. 2001, 52, 2207-2211. [CrossRef] [PubMed]

262. Khan, M.A.; Ahmed, M.Z.; Hameed, A. Effect of sea salt and 1-ascorbic acid on the seed germination of halophytes. J. Arid Environ. 2006, 67, 535-540. [CrossRef]

263. Corpas, F.J.; Hayashi, M.; Mano, S.; Nishimura, M.; Barroso, J.B. Peroxisomes are required for in vivo nitric oxide accumulation in the cytosol following salinity stress of Arabidopsis plants. Plant Physiol. 2009, 151, 2083-2094. [CrossRef] [PubMed]

264. Leterrier, M.; Barroso, J.B.; Valderrama, R.; Palma, J.M.; Corpas, F.J. NADP-Dependent Isocitrate Dehydrogenase from Arabidopsis Roots Contributes in the Mechanism of Defence against the Nitro-Oxidative Stress Induced by Salinity. Sci. World J. 2012, 694740.

265. Tanou, G.; Molassiotis, A.; Diamantidis, G. Hydrogen peroxide- and nitric oxide-induced systemic antioxidant prime-like activity under NaCl-stress and stress-free conditions in citrus plants. J. Plant Physiol. 2009, 166, 1904-1913. [CrossRef] [PubMed]

266. Dinler, B.S.; Antoniou, C.; Fotopoulos, V. Interplay between GST and nitric oxide in the early response of soybean (Glycine max L.) plants to salinity stress. J. Plant Physiol. 2014, 171, 1740-1747. [CrossRef]

267. Kaur, H.; Bhatla, S.C. Melatonin and nitric oxide modulate glutathione content and glutathione reductase activity in sunflower seedling cotyledons accompanying salt stress. Nitric Oxide. 2016, 59, 42-53. [CrossRef]

268. Akladious, S.A.; Mohamed, H.I. Physiological role of exogenous nitric oxide in improving performance yield and some biochemical aspects of sunflower plant under zinc stress. Acta Biol. Hung. 2017, 68, 101-114. [CrossRef]

269. Ahmad, P.; Ahanger, M.A.; Alyemeni, M.N.; Wijaya, L.; Alam, P.; Ashraf, M. Mitigation of sodium chloride toxicity in Solanum lycopersicum L. by supplementation of jasmonic acid and nitric oxide. J. Plant Interact. 2018, 13, 64-72. [CrossRef]

270. Hanafy, A.A.H.; Mohamed Hanaa, F.Y.; Orabi, I.O.A.; EL-Hefny, A.M. Influence of gamma rays, humic acid and sodium nitroprusside on growth, chemical constituents and fruit quality of snap bean plants under different soil salinity levels. Biosci. Res. 2018, 15, 575-588.

271. Beligni, M.V.; Lamattina, L. Nitric oxide interferes with plant photo-oxidative stress by detoxifying reactive oxygen species. Plant Cell Environ. 2002, 25, 737-748. [CrossRef]

272. Sheokand, S.; Bhankar, V.; Sawhney, V. Ameliorative effect of exogenous nitric oxide on oxidative metabolism in $\mathrm{NaCl}$ treated chickpea plants. Braz. J. Plant Physiol. 2010, 22, 81-90. [CrossRef] 
273. Manai, J.; Gouia, H.; Corpas, F.J. Redox and nitric oxide homeostasis are affected in tomato (Solanum lycopersicum) roots under salinity-induced oxidative stress. J. Plant Physiol. 2014, 171, 1028-1035. [CrossRef]

274. Hernández, J.A.; Díaz-Vivancos, P.; Barba-Espín, G.; Clemente-Moreno, M.J. On the role of salicylic acid in plant responses to environmental stresses. In Salicylic Acid: A Multifaceted Hormone; Nazar, R., Iqbal, N., Khan, N., Eds.; Springer: Singapore, 2017; pp. 17-34.

275. Rajjou, L.; Belghazu, M.; Huget, R.; Robin, C.; Moreau, A.; Job, C.; Job, D. Proteomic investigation of the effect of salicylic acid on Arabidopsis seed germination and establishment of early defense mechanisms. Plant Physiol. 2006, 141, 910-923. [CrossRef] [PubMed]

276. He, Y.; Zhu, Z.J. Exogenous salicylic acid alleviates $\mathrm{NaCl}$ toxicity and increases antioxidative enzyme activity in Lycopersicun esculentum. Biol. Plant. 2008, 52, 792-795. [CrossRef]

277. Szepesi, A.; Csiszára, J.; Gémesa, K.; Horvátha, E.; Horvátha, F.; Simonb, M.L.; Tari, I. Salicylic acid improves acclimation to salt stress by stimulating abscisic aldehyde oxidase activity and abscisic acid accumulation, and increases $\mathrm{Na}+$ content in leaves without toxicity symptoms in Solanum lycopersicum L. J. Plant Physiol. 2009, 166, 914-925. [CrossRef]

278. Kumara, G.D.K.; Xia, Y.; Zhu, Z.; Basnayake, B.M.V.S.; Beneragama, C.K. Effects of exogenous salicylic acid on antioxidative enzyme activities and physiological characteristics in gerbera (Gerbera jamesonii L.) grown under $\mathrm{NaCl}$ stress. J. Zhejiang Univ. Sci. 2010, 36, 591-601.

279. Lee, S.; Kim, S.G.; Park, C.M. Salicylic acid promotes seed germination under high salinity by modulating antioxidant activity in Arabidopsis. New Phytol. 2010, 188, 627-637. [CrossRef]

280. Hasanuzzaman, M.; Alam, M.M.; Nahar, K.; Mahmud, J.A.; Ahamed, K.U.; Fujita, M. Exogenous salicylic acid alleviates salt stress-induced oxidative damage in Brassica napus by enhancing the antioxidant defense and glyoxalase systems. Aust. J. Crop Sci. 2014, 8, 631-639.

281. Liu, S.; Dong, Y.; Kong, X.J. Effects of foliar application of nitric oxide and salicylic acid on salt-induced changes in photosynthesis and antioxidative metabolism of cotton seedlings. Plant Growth Regul. 2014, 73, 67-78. [CrossRef]

282. Nazar, R.; Umar, S.; Khan, N.A. Exogenous salicylic acid improves photosynthesis and growth through increase in ascorbate glutathione metabolism and $\mathrm{S}$ assimilation in mustard under salt stress. Plant Signal Behav. 2015, 10, e1003751. [CrossRef] [PubMed]

283. Palma, F.; López-Gómez, M.; Tejera, N.A.; Lluch, C. Salicylic acid improves the salinity tolerance of Medicago sativa in symbiosis with Sinorhizobium meliloti by preventing nitrogen fixation inhibition. Plant Sci. 2013, 208, 75-82. [CrossRef]

284. Barba-Espín, G.; Clemente-Moreno, M.J.; Alvarez, S.; García-Legaz, M.F.; Hernández, J.A.; Díaz-Vivancos, P. Salicylic acid negatively affects the response to salt stress in pea plants. Plant Biol. 2011, 13, 909-917. [CrossRef] [PubMed]

285. Radojičić, A.; Li, X.; Zhang, Y. Salicylic Acid: A Double-Edged Sword for Programed Cell Death in Plants. Front. Plant Sci. 2018, 9, 1133.

286. Sun, T.P.; Gubler, F. Molecular mechanism of gibberellin signaling in plants. Annu. Rev. Plant. Biol. 2004, 55, 197-223. [CrossRef]

287. Kaur, S.; Gupta, A.K.; Kaur, N. Gibberellin A3 reverses the effect of salt stress in chickpea (Cicer arietinum L.) seedlings by enhancing amylase activity and mobilization of starch in cotyledons. Plant Growth Regul. 1998, 26, 85-90. [CrossRef]

288. Maggio, A.; Barbieri, G.; Raimondi, G.; De Pascale, S. Contrasting effects of GA3 treatments on tomato plants exposed to increasing salinity. J. Plant Growth Regul. 2010, 29, 63-72. [CrossRef]

289. Ashraf, M.; Karim, F.; Rasul, E. Interactive effects of gibberellic acid (GA3) and salt stress on growth, ion accumulation and photosynthetic capacity of two spring wheat (Triticum aestivum L.) cultivars differing in salt tolerance. Plant Growth Regul. 2000, 36, 49-59. [CrossRef]

290. Acharya, U.T. Effect of GA3 on germination of paddy (Oryza sativa L. var. GR-3) under saline condition. Ph.D. Thesis, The Maharaja Sayajirao University Baroda, Vadodara, India, 1983.

291. Prakash, L.; Prathapasenan, G. Interactive effect of $\mathrm{NaCl}$ salinity and gibberellic acid on shoot growth, content of abscisic acid and gibberellin-like substances and yield of rice (Oryza sativa L. var GR-3). Proc. Indian Acad. Sci. 1990, 100, 173-181.

292. Wen, F.P.; Zhang, Z.H.; Bai, T.; Xu, Q.; Pan, Y.H. Proteomics reveals the effects of gibberellic acid (GA3) on salt-stressed rice (Oryza sativa L.) shoots. Plant Sci. 2010, 178, 170-175. [CrossRef] 
293. Liu, X.; Wang, X.; Yin, L.; Deng, X.; Wang, S. Exogenous application of gibberellic acid participates in up-regulation of lipid biosynthesis under salt stress in rice. Theor. Exp. Plant Phys. 2018, 30, 335-345. [CrossRef]

294. Alonso-Ramírez, A.; Rodríguez, D.; Reyes, D.; Jiménez, J.A.; Nicolás, G.; López-Climent, M.; Gómez-Cadenas, A.; Nicolás, C. Evidence for a Role of Gibberellins in Salicylic Acid-Modulated Early Plant Responses to Abiotic Stress in Arabidopsis Seeds. Plant Physiol. 2009, 150, 1335-1344. [CrossRef] [PubMed] 